Latvijas Lauksaimniecības universitāte

Lauksaimniecības fakultāte

Latvia University of Agriculture

Faculty of Agriculture

JĀNIS GAILIS

SKREJVABOLES (COLEOPTERA: CARABIDAE) KĀ INTEGRĒTĀS AUGU AIZSARDZĪBAS INDIKATORI KVIEŠU SĒJUMOS

\title{
GROUND BEETLES (COLEOPTERA: CARABIDAE) AS INDICATORS OF INTEGRATED PEST MANAGEMENT IN WHEAT FIELDS
}

Promocijas darba KOPSAVILKUMS

Dr. agr. zinātniskā grāda iegūšanai

SUMMARY

of the Doctoral Thesis for the scientific degree Dr. agr.

Jelgava, 2018 
Darba zinātniskais vadītājs / Scientific supervisor:

Dr. habil. agr. Ināra Turka

Darba recenzenti / Reviewers:

Dr. biol. Voldemārs Spuṇgis

Dr. biol. Līga Jankevica

Dr. biol. Edīte Kaufmane

Promocijas darba aizstāvēšana paredzēta Latvijas Lauksaimniecības universitātes Lauksaimniecības nozares Laukkopības apakšnozares promocijas padomes atklātajā sēdē 2018. gada 23. februārī plkst. 10.00, Latvijas Lauksaimniecības universitātē, 123. auditorijā, Lielā ielā 2, Jelgavā

The defence of Thesis will be held in open session of the Promotion Board of the Agriculture on February 23, 2018 at 10.00 in room 123, Latvia University of Agriculture, Lielā Street 2, Jelgava.

Ar promocijas darbu un tā kopsavilkumu var iepazīties Latvijas Lauksaimniecības universitātes Fundamentālajā bibliotēkā, Lielā iela 2, Jelgava.

The Thesis and summary are available at the Fundamental Library of Latvia University of Agriculture, Lielä Street 2, Jelgava.

Atsauksmes lūdzu sūtīt Lauksaimniecības nozares Laukkopības apakšnozares promocijas padomes sekretārei Dr. agr. Maijai Ausmanei, Lielā iela 2, Jelgava, LV-3001.

References are welcome to be sent to Dr. agr. Maija Ausmane, the Secretary of the Promotion Board, Latvia University of Agriculture, Lielā Street 2, Jelgava, $L V-3001$.

\section{groBioRes}

ISBN 978-9984-48-281-1

DOI: $10.22616 / 1$ uthesis/2018.001 


\section{Saturs \\ Contents}

Ievads 4

Pētījuma apstākḷi un metodika $\quad 7$

$\begin{array}{ll}\text { Rezultāti } & 13\end{array}$

Secinājumi 29

Pētījuma aprobācija 30

Approbation of the scientific work 30

Introduction 33

Research conditions and methodology 36

Results 40

$\begin{array}{ll}\text { Conclusions } & 47\end{array}$ 


\section{Ievads}

Integrētā augu aizsardzība ir praktisks instruments, kas būtiski ļauj samazināt ķīmisko augu aizsardzības līdzekḷu lietošanu, tajā pašā laikā saglabājot augstu kultūraugu ražību. Līdz ar to būtiski iespējams samazināt lauksaimniecības radīto slogu videi. Lai arī IAA pirmsākumi ir meklējami jau 20. gadsimta sākumā un pirmā tās definīcija publicēta 1959. gadā, praksē tā līdz šim ir ieviesta samērā gausi un smagnēji. Latvijā, saskaņā ar Augu aizsardzības likumu, IAA ieviešana saimniecībās ir obligāta kopš 2014. gada 1. janvāra. Šì prasība attiecas uz profesionāliem augu aizsardzības līdzekḷu lietotājiem, kuri izmanto otrās reǵistrācijas klases augu aizsardzības līdzekḷus vai kuri šîs klases augu aizsardzības līdzekḷu lietošanai izmanto profesionālu augu aizsardzības līdzekḷu lietotāju sniegtos pakalpojumus.

Viens no IAA elementiem ir dažādi kultūraugiem kaitīgo organismu dabiskie ienaidnieki, tajā skaitā skrejvaboles (Carabidae). Šīs dzimtas vaboles apdzīvo visas sauszemes ekosistēmas, ekologíiski ir saistītas ar augsnes virskārtu un ir saimnieciski nozīmīgi kaitīgo bezmugurkaulnieku un nezāḷu ierobežotāji dažādās agrocenozēs. Pētîjumi Eiropā un citur pasaulē ir apliecinājuši, ka skrejvaboles - to populāciju dinamiskais blīvums, sugu daudzveidība, sugu skaits un citi parametri - būtiski reaǵē uz dažādām vides faktoru izmaiņām, tajā skaitā agrotehniskām aktivitātēm agrocenozēs. Līdz ar to var uzskatīt, ka skrejvaboles spēj indicēt dažādus IAA pasākumus, jo pēc būtības IAA ir dažādu mērḳtiecīgu agronomisku darbību komplekss.

Promocijas darba aktualitāte. Nepieciešamība noteikt IAA indikatorus izriet no vairākiem politiskiem dokumentiem. Starptautiskā mērogā par to ir vienojusies OECD, kuras dalībvalsts kopš 2016. gada ir arī Latvija. Šì organizācija ir noteikusi divas IAA indikatoru grupas: intensitātes indikatorus (uptake indicators) un ietekmes indikatorus (impact indicators). Kā viens no IAA intensitātes indikatoriem ir minēti bioloǵiskās metodes kaitīgo sugu ierobežošanai izmantošanas rādītāji. Bet IAA ietekmes indikatori ir dažādi vides parametri, tajā skaitā biologiiskās daudzveidības rādītāji. Būtiskākās īpašības, kuras noteiktas potenciālajiem indikatoriem, ir vienkāršība (labi saprotami), salīdzināmība, zemas izmaksas, piesaistīts IAA definīcijai, izmantojams visās valstīs u.c. Šobrīd IAA indikatori vēl nav izstrādāti, bet galvenais OECD mērḳis ir izstrādāt ietekmes indikatorus, starp kuriem būtu iekḷaujami sauszemes biologiskās daudzveidības rādītāji. Skrejvaboles kā IAA elementi un biologiskās daudzveidības sastāvdaḷa var tikt izmantotas gan kā IAA intensitātes indikatori, gan ietekmes indikatori. Turklāt tām piemīt lielākā daḷa indikatoriem noteikto īpašību.

Latvijā IAA indikatoru izstrādi netieši nosaka LR MK 12.04.2013. rīkojums Nr. 146 „Par rīcības plānu augu aizsardzības līdzekḷu ilgtspējīgai izmantošanai 2013.-2015. gadam”. Šis dokuments paredz augu aizsardzības līdzekḷu lietošanas riska indikatoru noteikšanu. Tā kā IAA pamata mērḳis ir augu 
aizsardzības līdzekḷu radītā riska mazināšana, tad IAA indikatori varētu būt izmantojami kā zema augu aizsardzības līdzekḷ riska indikatori. Ne Latvijāā, ne Eiropā šādi indikatori nav izstrādāti, tāpēc MK rīkojumā ir ieteikts pagaidām izmantot biologiskās daudzveidības indikatorus, kas noteikti LR MK 24.02.2009. noteikumos Nr. 175 „Noteikumi par nacionālajiem vides indikatoriem". No šajā sarakstā minētajiem indikatoriem augu aizsardzības līdzekḷu ilgtspējīgu lietošanu vislabāk varētu atspoguḷot lauku putnu indekss un abinieku sugu indekss. Taču šie rādītāji ir atkarīgi ne tikai no augu aizsardzības līdzekḷu, bet vispārējā lauksaimniecības radītā sloga videi. Tā kā skrejvaboles agrocenozēs specifiski reaǵe uz augu aizsardzības līdzekḷu lietošanu, to sugu sabiedrības struktūra, sugu daudzveidība un citi parametri potenciāli varētu būt labāks pesticīdu ilgtspējīgas izmantošanas indikators.

Promocijas darba novitāte. Ne Latvijā, ne citur Eiropā IAA indikatori pagaidām nav izstrādāti. Tāpēc šì pētījuma ietvaros pirmo reizi būs noteikti IAA indikatori kviešu sējumiem.

Promocijas darba hipotēze. Skrejvaboles var būt izmantojamas par IAA indikatoriem kviešu sējumos.

Promocijas darba mērḳis. Noteikt kā un cik būtiski uz atšķirīgiem augsnes pamatapstrādes pan̄ēmieniem un atškirīīgām laukaugu maiṇas shēmām kviešu sējumos reaǵē dažādi ar skrejvabolēm saistīti parametri: sugu sabiedrība, dinamiskais blīvums, sugu daudzveidība.

Augsnes apstrāde un laukaugu maiņa ir vieni no svarīgākajiem IAA elementiem laukkopībā, tāpēc tieši šie agroekologiskie faktori tika izraudzīti pētījumam. Kviešu sējumi kā pētījuma vide tika izvēlēti tāpēc, ka Latvijas apstākḷıs šajās agrocenozēs nav nepieciešamība lietot insekticīdus. Līdz ar to kviešu sējumi ir piemērota vide šim pētījumam, jo tajos iegūtos datus augu aizsardzības līdzekḷu lietošana tieši neietekmē.

\section{Promocijas pētijuma uzdevumi:}

1) aprēḳināt skrejvaboḷu dominances struktūras un sugu daudzveidību, kā arī noteikt sugu populāciju dinamiskos blīvumus atšķirīgi apsaimniekotajos parauglaukumos;

2) noteikt, cik būtiski minētos, ar skrejvabolēm saistîtos, parametrus ietekmē atšķirīgie augsnes pamatapstrādes paņēmieni un ziemas kviešu priekšaugi;

3) noteikt potenciālos IAA indikatorus kviešu sējumos.

\section{Pierādāmās tēzes:}

1) atšķirīgi augsnes pamatapstrādes paṇēmieni un priekšaugi būtiski ietekmē skrejvaboḷu sugu sabiedrību kviešu sējumos;

2) atšķirīgi augsnes pamatapstrādes paņēmieni un priekšaugi būtiski ietekmē skrejvaboḷu kopējo dinamisko blīvumu, biežāk sastopamo sugu dinamisko blīvumu un sugu ekologisko grupu dinamisko blīvumu kviešu sējumos; 
3) atšḳirīgi augsnes pamatapstrādes paṇēmieni un priekšaugi būtiski ietekmē skrejvaboḷu sugu daudzveidību kviešu sējumos.

Promocijas pētijums veikts divu projektu ietvaros:

1) Valsts Pētījumu programmas projekta „Vietējo lauksaimniecības resursu ilgtspējīga izmantošana paaugstinātas uzturvērtības pārtikas produktu izstrādei (PĀRTIKA)” 3.1. apakšprojekts „Augsnes kā galvenā resursa ilgtspējīga izmantošana drošu un kvalitatīvu pārtikas un lopbarības izejvielu ieguvei no plašāk audzētajām laukaugu sugām" (2012.-2013. gads).

2) Valsts Pētîjumu programmas "Lauksaimniecības resursi ilgtspējīgai kvalitatīvas un veselīgas pārtikas ražošanai Latvijā" projekts "Augsnes ilgtspējīga izmantošana un mēslošanas risku mazināšana" (kopš 2014. gada).

Pētījuma rezultātu aprobācija. Par šī pētījuma rezultātiem ir sniegti septiņi ziņojumi starptautiskās zinātniskās konferencēs un trīs ziņojumi Latvijas mēroga zinātniskās konferencēs. Publicēti četri raksti zinātniskos žurnālos, kuri indeksēti Scopus vai Thomson Reuters Web of Science datubāzēs, divi raksti citos zinātniskos žurnālos un viens raksts populārzinātniskā žurnālā, kā arī astoṇas zinātnisku konferenču tēzes. 


\section{Pētījuma apstākḷi un metodika}

Pētījuma vietas un apstākḷu apraksts. Pētījums tika veikts 2012.2014. gadā agronomisko izmēgininājumu stacionārā, kurš atrodas Jelgavas novada Platones pagastā, LLU Mācību un pētījumu saimniecībā (MPS) "Pēterlauki" netālu no Poķu ciemata, 14 kilometrus uz dienvidiem no Jelgavas (56 30'39.38' 'Z; 2341'30.15' A). Agronomisko pētījumu stacionārs izveidots 2009. gadā plašiem labas lauksaimniecības prakses pētîjumiem Latvijā biežāk izplatītajos laukaugu sējumos. Stacionāru veidoja 24 taisnstūrveida parauglaukumu režğis. Katra parauglaukuma izmēri bija 30 x $85 \mathrm{~m}$, bet platība 0.25 ha. Parauglaukumu režği ieskāva konvencionāli apstrādāta aramzeme, bet $30 \mathrm{~m}$ uz dienvidiem atradās šaura $(35$ x $510 \mathrm{~m})$ meža josla, kuru veidoja aptuveni 60 gadus vecs lapkoku mežs, kas attīstījies uz agrāk lauksaimniecībā izmantotas zemes. Tuvākās ēkas atradās $120 \mathrm{~m}$ uz rietumiem no pêtījumā izmantotā parauglaukumu režǵa. Parauglaukumi gan savstarpēji, gan no apkārt esošajiem laukiem bija atdalīti ar 2.5 m platām zemes joslām, kuras klāja savval̨as lakstaugu veg̣etācija. Kopš stacionāra izveidošanas visas aktivitātes, piemēram, augsnes apstrāde, laukaugu sēja, minerālmēslu un pesticīdu lietošana, ražas novākšana utt. veikta atbilstoši konvencionālās lauksaimniecības prakses principiem, izmantojot tradicionālu lauksaimniecības tehniku, kā tas būtu darîts jebkurā, komerciālos nolūkos izmantotā, laukā.

Pêtījuma vietā bija virsēji glejota smilšmāla augsne (GLu) ar $\mathrm{pH} \mathrm{KCl} 6.8$ un zemu humusa saturu $-20 \mathrm{~g} \mathrm{~kg}^{-1}$. Visos parauglaukumos ir izmantoti divi atšķirīgi galvenie augsnes apstrādes pan̄ēmieni. Kopš režğa izveidošanas 12 parauglaukumi katru rudeni tika arti, izmantojot vērstuvju arklu. Aršanas dziḷums $0.22-0.23 \mathrm{~m}$. Pārējos 12 parauglaukumos augsnes virskārta netika apvērsta. To augsnes apstrādes galvenais pan̄ēmiens bija uzlob̄išana 0.10-0.11 m dziḷumā, izmantojot disku ecēšas (turpmāk tekstā - diskošana). Pārējās augsnes apstrādes aktivitātes parauglaukumos tika veiktas atbilstoši tradicionālai lauksaimniecības praksei kā jebkurā komerciālā laukā.

Pētijjums katru gadu tika veikts sešos artos un sešos diskotos parauglaukumos, kuri bija apsēti ar ziemas kviešiem (šķirne 'Zentos') 2012. un 2013. gadā. Savukārt 2014. gadā pētījumā izmantotajos 12 parauglaukumos bija iesēti vasaras kvieši (škirne 'Taifun'), jo ziemas kvieši 2013./2014. gada ziemā izsala. Pārējie stacionāra parauglaukumi katru gadu bija apsēti ar citiem laukaugiem. Tādējādi katrā pētījuma gadā veidojās vairākas divu agroekolog̣isko faktoru kombinācijas: augsnes pamatapstrādes veids un priekšaugs. Vasaras kvieši, ziemas kvieši un vasaras rapsis bija ziemas kviešu priekšaugi ik divos diskotajos un artajos parauglaukumos 2012. gadā. Līdz ar to šajā veǵetācijas sezonā veidojās sešas abu faktoru kombinācijas. Četras abu faktoru kombinācijas bija 2013. gadā, kad četros artajos un četros diskotajos parauglaukumos ziemas kviešu priekšaugs bija vasaras rapsis, bet divos artajos un divos diskotajos parauglaukumos - ziemas kvieši. Piecas abu faktoru kombinācijas bija 
izveidojušās 2014. gadā, kad vasaras kviešu parauglaukumos priekšaugi bija ziemas kvieši un vasaras un ziemas rapsis. Šajā pētījumā 2014. gada rezultāti ir analizēti četru kombināciju ietvaros: divi arti un divi diskoti parauglaukumi ar ziemas kviešiem kā priekšaugu, kā arī četri arti un četri diskoti parauglaukumi ar rapsi kā priekšaugu (1. att.).

Pēc ražas novākšanas salmi un citas augu atliekas tika atstātas parauglaukumos kā mēslojums, taču augsnes mēslošanai katru gadu tika izmantoti arī minerālmēsli. Ar kviešiem apsētajos, pētījumā izmantotajos, parauglaukumos katru gadu tika lietoti Latvijā reǵistrēti herbicīdi, fungicīdi un augšanas regulatori. Insekticīdi un citi augu aizsardzības līdzekḷi dzīvnieku valsts nevēlamo organismu ierobežošanai netika izmantoti. Visi augu aizsardzības līdzekḷi tika lietoti nepieciešamības gadījumos, kad to noteica nezāḷu un augu slimību monitoringa rezultāti.

Sārtā panātre (Lamium purpureum), tīruma veronika (Veronica arvensis), ķerainu madara (Galium aparine) un maura sūrene (Polygonum aviculare) bija visbiežāk sastopamās nezāḷ sugas visos pētījuma parauglaukumos. Taču diskotajos parauglaukumos, kuros katru gadu kvieši tika sēti pēc kviešiem, arī parastā rudzusmilga (Apera spica-venti) bija viena no dominējošajām nezāḷu sugām. Kopējais nezāḷ blīvums parauglaukumos tika novērtēts divas reizes katrā pētījuma gadā. Pirmā uzskaite 2012. un 2013. gadā tika veikta maija pirmajā dekādē, attiecīgi 3. maijā un 10. maijā. Savukārt 2014. gadā pirmā nezāḷu uzskaite veikta maija trešajā dekādē - 22. maijā. Otrā nezāḷ uzskaite 2012. un 2013. gadā veikta jūlija pirmajā dekādē, attiecīgi 9. jūlijā un 8. jūlijāa, bet 2014. gadā - jūlija trešajā dekādē, 24. jūlijā. Katrā gadā, aptuveni vienu nedēlu pēc pirmās nezālu uzskaites, veikta nezāļu ierobežošana, izmantojot herbicīdu. Taču 2014. gadā parauglaukumi tika apsmidzināti ar herbicīdu (glifosātu saturošu) arī pirms vasaras kviešu sējas. 2012. un 2014. gadā nezāḷu ḳīmiskā ierobežošana bija sekmīga, nezāḷu blīvums parauglaukumos ievērojami samazinājās. Taču 2013. gadā pēc herbicīda lietošanas nezāḷ blīvums atsevišķos parauglaukumos samazinājās minimāli, bet lielākajā daḷā parauglaukumu tas ievērojami pieauga (1. att.).

Katrā pētījuma gadā parauglaukumos tika reǵistrēta diennakts vidējā gaisa temperatūra un nokrišņu daudzums, izmantojot Davis Vantage Pro2 meteoroloǵisko staciju, kura atradās $100 \mathrm{~m}$ attālumā no pētījumu stacionāra. Meteorologisko faktoru dinamika aplūkojama 2. attēlā.

Skrejvaboḷu vākšanas, apstrādes un datu analīzes metodes. Skrejvaboles tika vāktas, izmantojot Bārbera augsnes lamatas - caurspīdīgas plastmasas glāzes, kuras līdz augšmalai ieraktas augsnē. Lamatu atvēruma diametrs bija $65 \mathrm{~mm}$, bet tilpums $200 \mathrm{~cm}^{3}$. Katrā parauglaukumā tika uzstādītas 10 lamatas pa parauglaukuma diagonāli novilktā transektē, attālums starp lamatām bija trīs metri. Skrejvaboḷu fiksēšanai lamatas līdz pusei bija piepildītas ar 4-5 \% etiḳskābes šḳīdumu, kam pievienoti vairāki pilieni deterğenta. Pirmajos divos pētījuma gados lamatu eksponēšana tika uzsākta 


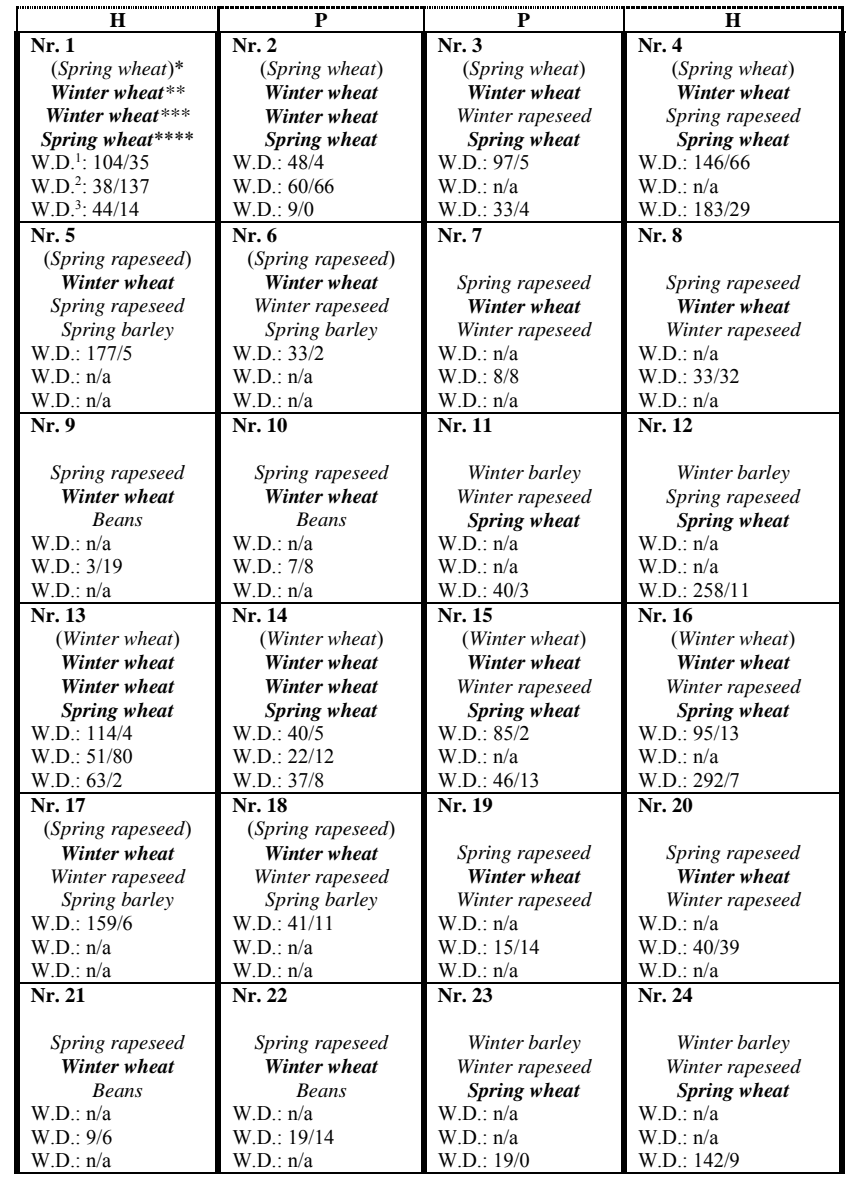

1. att. Pētījumā izmantoto parauglaukumu shēma 2012.-2014. gadā

Augsnes pamatapstrādes paņēmiens: $\mathrm{H}$ - diskots, $\mathrm{P}$ - arts; *- laukaugs 2011. gadā (norādīts parauglaukumiem, kuros 2012. gadā auga ziemas kvieši), ** - laukaugs 2012. gadā, *** - laukaugs 2013. gadā, *** - laukaugs 2014. gadā; W.D. ${ }^{1}$ - nezālu blīvums 2012. gadā (augi m ${ }^{-2}$ 3. maijā/9. jūlijā), W.D. ${ }^{2}$ - nezāḷu blīvums 2013. gadā (augi $\mathrm{m}^{-2}$ 10. maijā/8. jūlijā), W.D. ${ }^{3}$ - nezāļu blīvums 2014. gadā (augi m ${ }^{-2}$ 22. maijā/24. jūlijā); nezāḷu blīvums norādīts parauglaukumiem, kuri tika izmantoti pētījumā.

\section{Fig. 1. Scheme of sample plots used for the research during 2012-2014} Main soil treatment: $H$ - harrowed, $P$ - ploughed; * crop in 2011 (showed only in sample plots sown with winter wheat in 2012); ** - crop in 2012, *** - crop in 2013, **** - crop in 2014; W.D. ${ }^{I}$ - density of weeds in 2012 (plants $m^{-2}$ May 3/July 9), W.D. ${ }^{2}$ - density of weeds in 2013 (plants $m^{-2}$ May 10/July 8), density of weeds in 2014 (plants $m^{-2}$ May 22/July 24); density of weeds is showed only for sample plots used for the study. 

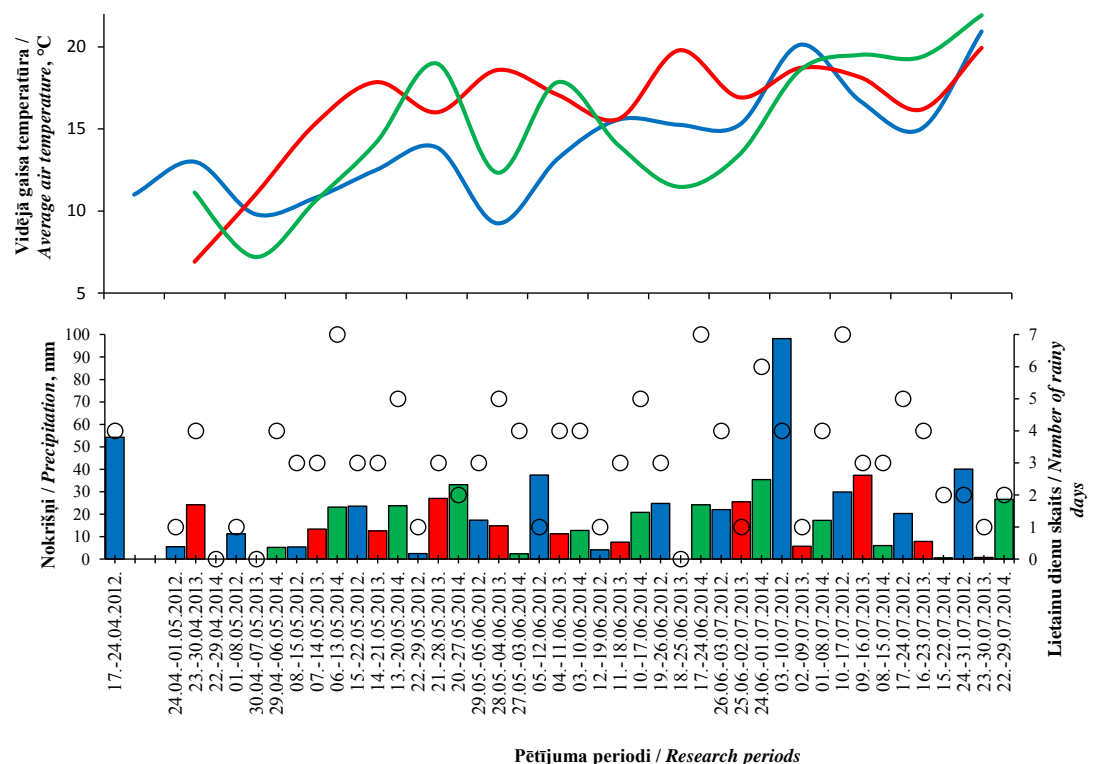

2. att. Meteorologiskie faktori parauglaukumos skrejvaboḷu pētījumu periodos 2012.-2014. gadā

—_ gaisa temperatūra 2012. gadā; _— - gaisa temperatūra 2013. gadā; —— - gaisa temperatūra 2014. gadā; " - nokrišņi 2012. gadā; n - nokrišņi 2013. gadā; = - nokrišņi 2014. gadā; ○ - lietainu dienu skaits.

\section{Fig. 2. Meteorological conditions in sample plots during research periods of ground beetles in 2012-2014}

air temperature in $2012 ;-$ - air temperature in 2013; _- air

temperature in 2014; - - precipitation in 2012; - - precipitation in 2013;

- precipitation in 2014; 0 - number of rainy days).

pavasarī, kad dabā tika novērotas pirmās aktīvās skrejvaboles. Tas notika attiecīgi 2012. gada 17. aprīlī un 2013. gada 23. aprīî̄. Trešajā pētījuma gadā (2014. gadā) lamatu eksponēšana tika uzsākta 22. aprīlī jeb trīs dienas pēc izsalušo ziemas kviešu sējumu pārsēšanas ar vasaras kviešiem. Iekritušās vaboles no lamatām tika izṇemtas, un lamatas tika piepildītas ar svaigu etiksskābes šḳ̄iumu reizi septin̄ās dienās. Lamatu eksponēšana tika pabeigta attiecīgi 2012. gada 31. jūlijā, 2013. gada 30. jūlijā un 2014. gada 29. jūlijā. Pirmajos divos gados tas bija attiecīgi divas un četras dienas pirms ziemas kviešu noplaušanas. Savukārt trešajā gadā lamatu eksponēšana tika pārtraukta 25 dienas pirms vasaras kviešu noplaušanas. Tāds lēmums tika pieņemts tāpēc, ka par šo 25 dienu periodu nebija iespējams iegūt salīdzināmus datus no pirmajiem diviem pētījuma gadiem. 
Lamatās iekritušo skrejvaboḷu materiāls ir aprīkots ar atbilstošām etiķetēm un tiek uzglabāts $70 \%$ etilspirta škīdumā LLU Lauksaimniecības fakultātes Augsnes un augu zinātņu institūtā Jelgavā, Strazdu ielā 1. Skrejvaboḷu sugas tika noteiktas, izmantojot Viduseiropas vaboḷu noteicēju. Sugu nosaukumi šajā darbā ir lietoti atbilstoši Latvijas vaboḷu sugu sarakstam.

Skrejvaboḷu sugu sabiedrības tika analizētas, aprēkinot sugu dominances struktūru atbilstoši H.-D. Engelmana ieteiktajai skalai. Saskaṇā ar šo skalu sugas tiek sadalītas piecās grupās atkarībā no to indivīdu īpatsvara sugu sabiedrībā:

1) eidominantas sugas $(40.0-100.0 \%)$;

2) dominantas sugas $(12.5-39.9 \%)$;

3) subdominantas sugas $(4.0-12.4 \%)$;

4) recedentas sugas $(1.3-3.9 \%)$;

5) subrecedentas sugas $(<1.3 \%)$.

Tika veikts gan summārais, gan fenologiskais dominances struktūras aprēḳins katrai augsnes pamatapstrādes pan̄ēmiena un priekšauga kombinācijai katram pētījuma gadam. Lai parauglaukumos ar attiecīgo agroekologisko faktoru kombināciju aprēkinātu katras sugas gada summāro īpatsvaru, tika izmantots konkrētās sugas indivīdu skaits un visu skrejvaboḷu indivīdu skaits, kas notverti visas pētījumu sezonas laikā visās attiecīgajos parauglaukumos eksponētajās augsnes lamatās. Fenoloǵiskajam aprēḳinam tika izmantots katras konkrētās sugas indivīdu skaits un visu skrejvaboḷu indivīdu skaits, kas notverti visās katras faktoru kombinācijas parauglaukumu lamatās katrā septinu dienu pētījuma periodā. Gada summārie aprēḳini tika veikti, lai analizētu abu agroekologisko faktoru ietekmi uz skrejvaboḷu sugu sabiedrību, bet fenologiskie aprēķini tika veikti, lai noteiktu kviešu sējumos biežāk sastopamās sugas veǵetācijas sezonas gaitā. Sugām, kuras sasniedza subdominantu vai augstāku stāvokli vismaz vienā pētījumu periodā vismaz vienā agroekologisko faktoru kombinācijā, tika veikta dinamiskā blīvuma atkarības pārbaude no abiem agroekologiskajiem faktoriem un to kombinācijām.

Biežāk sastopamo sugu un visu sugu summārā dinamiskā blīvuma atkarība no abiem agroekologiskajiem faktoriem tika analizēta, izmantojot vienfaktora dispersijas analīzi. Ja, veicot šo analīzi, tika konstatēts, ka skrejvaboḷu dinamisko blīvumu vai novēroto sugu skaitu statistiski būtiski $(\mathrm{p} \leq 0.05)$ ietekmējis priekšaugs 2012. gada sezonā vai abu faktoru kombinācija jebkurā pētījuma sezonā, tad tika izmantots Scheffé's post-hoc tests. Ar to tika noteikts, kura priekšauga vai kuras faktoru kombinācijas radītajos apstākḷos pētîtie skrejvaboḷu parametri ir bijuši būtiski atšķirīgi. Dispersijas analīze un post-hoc tests, ja bija nepieciešams, tika veikts katram pētījuma periodam, iegūstot fenologisku faktoru ietekmes ainu uz skrejvaboḷ dinamisko blīvumu.

Skrejvaboḷu sugu daudzveidība tika noteikta, aprēḳinot Simpsona indeksu $\left(D_{s}\right)$ :

$$
D_{s}=\sum \frac{n_{i}\left(n_{i}-1\right)}{N(N-1)}
$$


kur:

$\mathrm{n}_{\mathrm{i}}$ - i-tās skrejvaboḷu sugas indivīdu skaits lamatās;

$\mathrm{N}$ - visu skrejvaboḷu indivīdu skaits lamatās.

Jo lielāka sugu daudzveid̄̄ba, jo Simpsona indeksa skaitliskā vērtība ir mazāka. Tāpēc labākas uzskatāmības nolūkos šajā pētījumā tika izmantots reciprokālais Simpsona indekss $\left(1 / \mathrm{D}_{\mathrm{s}}\right)$, kura skaitliskā vērtība palielinās, pieaugot sugu daudzveidībai. Šis rādītājs tika noteikts visām 120 pētījumā izmantotajām augsnes lamatām katrā pētījumu sezonā. Indeksa aprēķināšanai tika izmantoti katru lamatu gada summārie dati - katras skrejvaboḷu sugas gada summārais indivīdu skaits un visu skrejvaboḷu gada summārais indivīdu skaits.

Sakarība starp skrejvaboḷu sugu daudzveidību un pētītajiem agroekoloǵiskajiem faktoriem tika novērtēta, aprēḳinot Spīrmena rangu korelācijas koeficientu $\left(\mathrm{r}_{\mathrm{s}}\right)$ ar divvirzienu būtiskuma testu. Katrai pētījumu sezonai korelācija tika rēḳināta septiņos dažādos variantos 2012. gada sezonai un sešos dažādos variantos pērējām divām sezonām:

1) starp sugu daudzveidību un augsnes pamatapstrādes veidu neatkarīgi no priekšauga;

2) starp sugu daudzveidību un priekšaugu neatkarīgi no augsnes pamatapstrādes veida;

3) starp sugu daudzveidību un priekšaugu diskotā augsnē;

4) starp sugu daudzveidību un priekšaugu artā augsnē;

5) starp sugu daudzveid̄̄bu un augsnes pamatapstrādes veidu, ja priekšaugs rapsis;

6) starp sugu daudzveidību un augsnes pamatapstrādes veidu, ja priekšaugs ziemas kvieši;

7) starp sugu daudzveidību un augsnes pamatapstrādes veidu, ja priekšaugs vasaras kvieši (tikai 2012. gada sezonai).

Korelācijas stiprums tika noteikts pēc šādas skalas:

$$
\begin{aligned}
& \left|\mathrm{r}_{\mathrm{s}}\right|=0.00-0.19 \text { - l,oti vāja korelācija; } \\
& \left|\mathrm{r}_{\mathrm{s}}\right|=0.20-0.39 \text { - vāja korelācija; } \\
& \left|\mathrm{r}_{\mathrm{s}}\right|=0.40-0.59 \text { - vidēji stipra korelācija; } \\
& \left|\mathrm{r}_{\mathrm{s}}\right|=0.60-0.79 \text { - stipra korelācija; } \\
& \left|\mathrm{r}_{\mathrm{s}}\right|=0.80-1.00 \text { - l̦oti stipra korelācija. }
\end{aligned}
$$

Visi statistiskie aprēķini tika veikti, izmantojot programmu SPSS 22.0. Ar vienām lamatām iegūtie rādītāji (vaboḷu dinamiskais blīvums, reciprokālais Simpsona indekss) tika izmantoti kā viens atkārtojums. 


\section{Rezultāti}

Skrejvaboḷu sugu sabiedrības atšķirīgi apsaimniekotos kviešu sējumos. Visos trīs pētījuma gados, kopā skaitot, parauglaukumos konstatēti 113946 skrejvaboḷu indivīdi no 75 sugām. Novēroto indivīdu skaits svārstījies pa pētījuma sezonām. Pirmajā sezonā lamatās tika notvertas 25369 skrejvaboles, otrajā sezonā - 60024 skrejvaboles, bet trešajā sezonā - 28563 skrejvaboles. Daḷa sugu parauglaukumos bija sastopamas tikai vienā vai divos pētījuma gados. Līdz ar to 2012. gadā novērotas 66 sugas, 2013. gadā - 57 sugas un 2014. gadā -45 sugas.

Gada summārās biežāk sastopamo jeb dominējošo skrejvaboḷu sugu sabiedrības visās pētījuma sezonās lielākoties veidoja vienas un tās pašas sugas. Taču bija novērojamas šo sabiedrību atšķirības gan starp dažādi apsaimniekotajiem parauglaukumiem vienas pētījuma sezonas ietvaros, gan arī starp dažādām pētījuma sezonām. 2012. gada sezonā nevienā no parauglaukumiem netika novērotas eidominantas sugas. Divas sugas - Loricera pilicornis un Bembidion guttula - bija visdominējošākās sugas visos parauglaukumos. Neatkarīgi no priekšauga L. pilicornis bija visbiežāk sastopamā suga diskotajos parauglaukumos, bet $B$. guttula - artajos parauglaukumos. Vēl sešas sugas - Bembidion obtusum, Poecilus cupreus, Harpalus rufipes, Pterostichus melanarius, Pterostichus niger un Amara plebeja - sasniedza vismaz subdominantu stāvokli parauglaukumos ar vismaz vienu augsnes pamatapstrādes paņēmiena un priekšauga kombināciju (3. att.).

2013. gada sezonā biežāk sastopamo skrejvaboḷu sugu sabiedrības parauglaukumos veidoja gandrīz visas tās pašas sugas, kuras 2012. gadā, taču dominances struktūra bija būtiski atšķirīga. Piecas sugas $-H$. rufipes, $P$. niger, $P$. melanarius, $P$. cupreus un $B$. guttula - sasniedza vismaz subdominantu ipatsvaru visos parauglaukumos, bet $L$. pilicornis bija subdominanta visos parauglaukumos, izņemot tos, kuriem bija arta augsne un ziemas kvieši priekšaugs (4. att.). H. rufipes ievērojami dominēja pār citām sugām visos parauglaukumos, bet visizteiktāt tas bija vērojams jau minētajos parauglaukumos ar artu augsni un ziemas kviešiem kā priekšaugu, kur $H$. rufipes sasniedza eidominantu stāvokli. Salīdzinot ar 2012. gada sezonu, īpatsvars ievērojami bija pieaudzis arī abām Pterostichus sugām, kā arī $P$. cupreus. Turpretī B. guttula un L. pilicornis īpatsvars bija ievērojami samazinājies. Abas sugas spēja sasniegt maksimums subdominantu stāvokli. Savukārt A. plebeja un B. obtusum 2013. gada sezonā nevienā parauglaukumā nesasniedza pat subdominantu līmeni, lai arī to dinamiskais blīvums bija salīdzinoši liels.

2014. gada sezonā tikai piecas skrejvaboḷu sugas $-P$. melanarius, $P$. niger, $H$. rufipes, $P$. cupreus un $B$. guttula sasniedza vismaz subdominantu līmeni parauglaukumos ar vismaz vienu priekšauga un augsnes pamatapstrādes veida kombināciju. Dominances struktūra parauglaukumos ar diskotu augsni un 

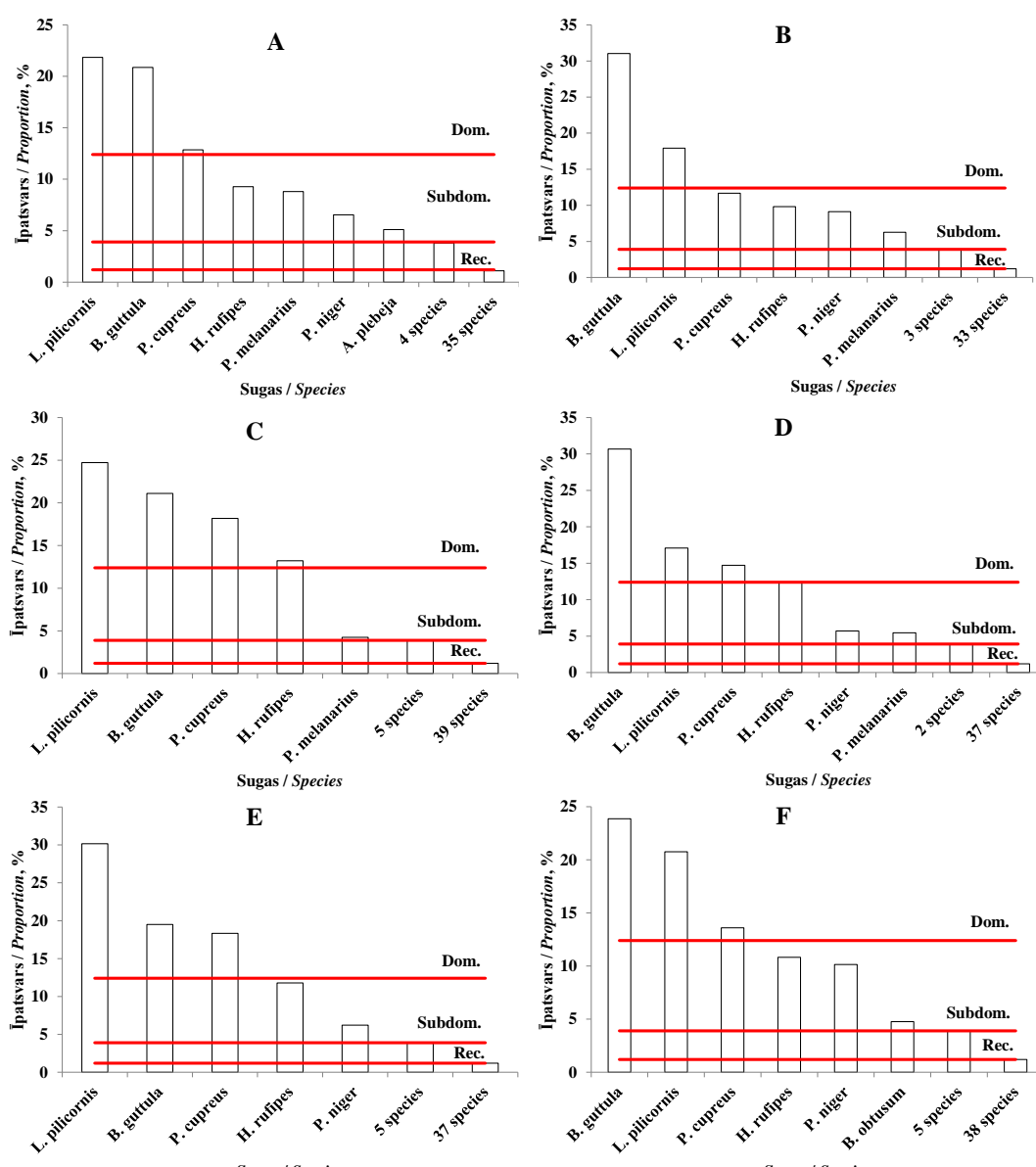

3. att. Skrejvaboḷu sugu dominances struktūras ziemas kviešu parauglaukumos ar atšḳirīgiem augsnes pamatapstrādes paṇēmieniem un priekšaugiem 2012. gadā A - diskota augsnes, vasaras kvieši priekšaugs; B - arta augsnes, vasaras kvieši priekšaugs; C - diskota augsnes, ziemas kvieši priekšaugs; D - arta augsnes, ziemas kvieši priekšaugs; E - diskota augsnes, rapsis priekšaugs; F - arta augsnes, rapsis priekšaugs; Dom. - dominantas sugas, Subdom. - subdominantas sugas, Rec. recedentas sugas.

\section{Fig. 3. Dominance structure of ground beetles in differently tilled and pre-cropped winter wheat sample plots in 2012}

$A$ - harrowed soil, spring wheat as pre-crop; $B$-ploughed soil, spring wheat as precrop; $C$-harrowed soil, winter wheat as pre-crop; $D$ - ploughed soil, winter wheat as pre-crop; E-harrowed soil, rapeseed as pre-crop; $F$ - ploughed soil, rapeseed as precrop; Dom. - dominant species; Subdom. - subdominant species, rec. - recedent species. 

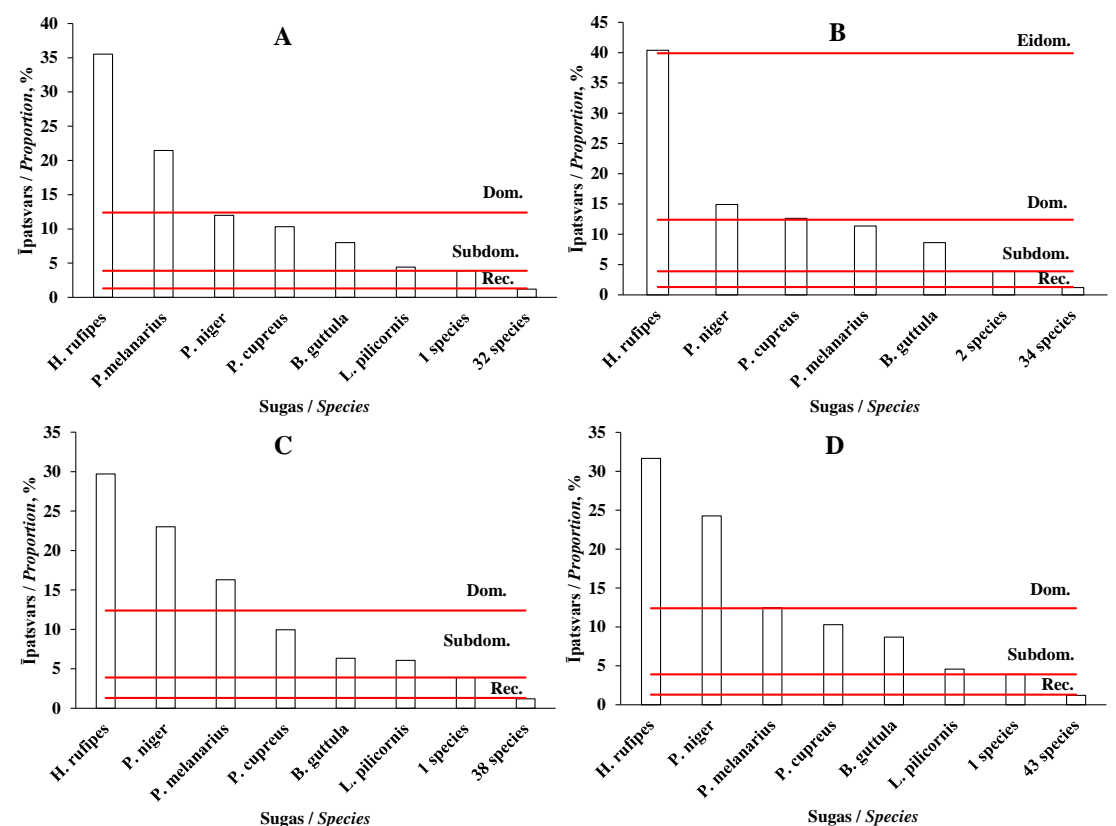

4. att. Skrejvaboḷu sugu dominances struktūras ziemas kviešu parauglaukumos ar atšḳirīgiem augsnes pamatapstrādes paṇēmieniem un priekšaugiem 2013. gadā A - diskota augsnes, ziemas kvieši priekšaugs; B - arta augsnes, ziemas kvieši priekšaugs; C - diskota augsnes, rapsis priekšaugs; D - arta augsnes, rapsis priekšaugs; Eidom. - eidominantas sugas, Dom. - dominantas sugas, Subdom. - subdominantas sugas, Rec. - recedentas sugas.

\section{Fig. 4. Dominance structure of ground beetles in differently tilled and pre-cropped winter wheat sample plots in 2013}

$A$ - harrowed soil, winter wheat as pre-crop; $B$-ploughed soil, winter wheat as precrop; $C$-harrowed soil, rapeseed as pre-crop; $D$ - ploughed soil, rapeseed as precrop; Eidom. - Eudominant species; Dom. - dominant species; Subdom. - subdominant species, rec. - recedent species.

ziemas kviešiem kā priekšaugu no dominances struktūrām pārējos parauglaukumos atškīīās viskrasāk. Šajos parauglaukumos $P$. melanarius bija eidominanta suga, $H$. rufipes - dominanta suga, bet $P$. niger - subdominanta suga. Pārējo sugu īpatsvari šajos parauglaukumos atbilda recedentam vai subrecedentam statusam. Pārējos parauglaukumos trīs minētās sugas sasniedza dominantu stāvokli, bet $P$. cupreus bija subdominanta. Savukārt B. guttula sasniedza subdominantu lìmeni tikai parauglaukumos, kuros priekšaugs bija rapsis neatkarīgi no augsnes pamatapstrādes paņēmiena (5. att.).

Skrejvaboḷu dinamiskais blīvums un līdz ar to arī to indivīdu īpatsvars sugu sabiedrībā var būtiski svārstīties starp dažādiem gadiem. To tieši un 

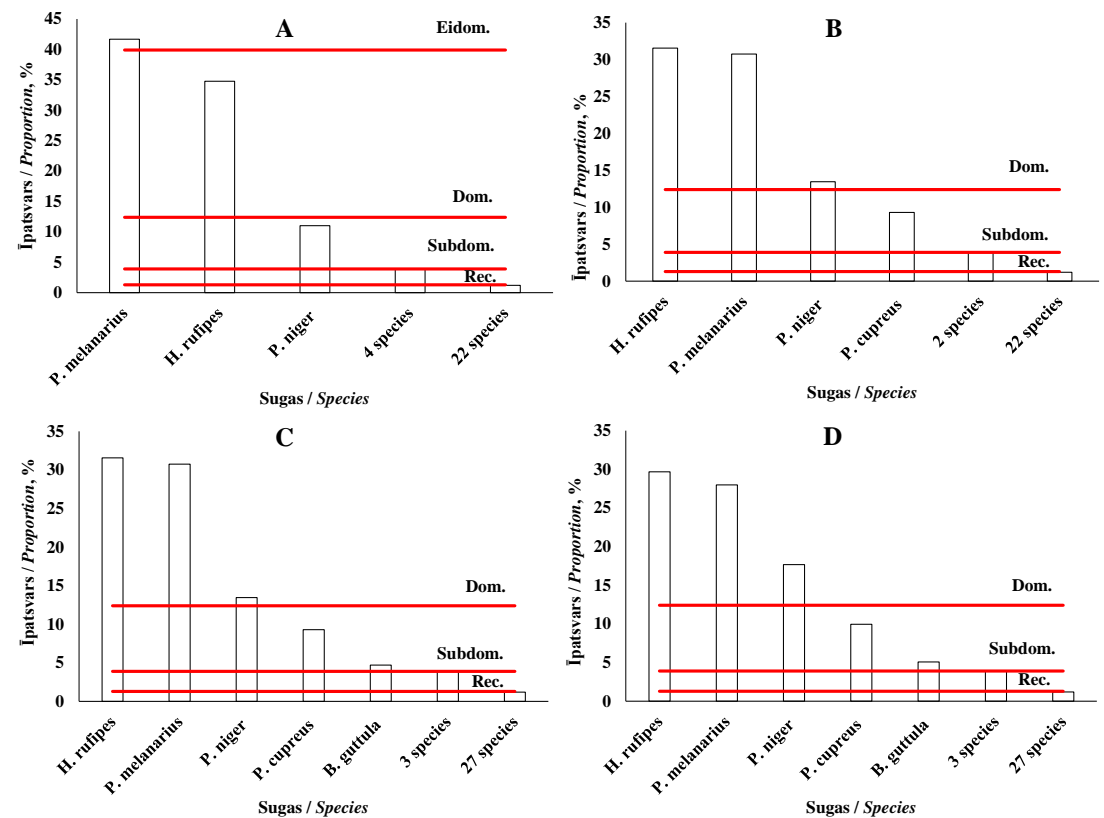

5. att. Skrejvaboḷu sugu dominances struktūras vasaras kviešu parauglaukumos ar atšḳirīgiem augsnes pamatapstrādes paṇēmieniem un priekšaugiem 2014. gadā

A - diskota augsnes, ziemas kvieši priekšaugs; B - arta augsnes, ziemas kvieši priekšaugs; C - diskota augsnes, rapsis priekšaugs; D - arta augsnes, rapsis priekšaugs; Eidom. - eidominantas sugas, Dom. - dominantas sugas, Subdom. - subdominantas sugas, Rec. - recedentas sugas.

\section{Fig. 5. Dominance structure of ground beetles in differently tilled and pre-cropped} spring wheat sample plots in 2014

$A$ - harrowed soil, winter wheat as pre-crop; $B$-ploughed soil, winter wheat as precrop; $C$ - harrowed soil, rapeseed as pre-crop; $D$ - ploughed soil, rapeseed as precrop; Eidom. - Eudominant species; Dom. - dominant species; Subdom. - subdominant species, rec. - recedent species.

netieši ietekmē meteoroloǵiskie apstākḷi. 2012. gada sezona, salīdzinot ar pārējām divām, bija vēsāka un lietaināka. Ja ir daudz nokrišnu, tad agrocenozē var būt vairāk sastopamas higrofîlas skrejvaboḷu sugas, piemēram, B. guttula. Nokrišņi arī veicina lielāku kolembolu (Collembola) blīvumu augsnes virskārtā, bet kolembolas ir L. pilicornis galvenā barības bāze. Gaisa temperatūra var ietekmēt skrejvaboḷu vairošanās ciklus. Lielāks $P$. niger un $P$. melanarius populācijas blīvums ir novērojams pēc salīdzinoši vēsākām vasarām.

Vairāku skrejvaboḷu sugu īpatsvaru ietekmēja pētītie agroekoloǵiskie faktori. L. pilicornis īpatsvars pirmajās divās sezonās bija redzami lielāks diskotā 
augsnē. $P$. niger ievērojami biežāk bija sastopama parauglaukumos, kur tiek veikta laukaugu maina, savukārt $P$. melanarius īpatsvaram bija tendence būt lielākam parauglaukumos bez augu maiņas. Pirmajā pētījuma sezonā $B$. guttula deva priekšroku artai augsnei, bet $A$. plebeja - diskotai augsnei kombinācijā ar priekšaugu vasaras kvieši, bet citos parauglaukumos bija novēroti atsevišķi šīs sugas indivīdi. Lielais A. plebeja īpatsvars veidojās parauglaukumos, kuros arī pēc herbicīdu smidzināšanas saglabājās salīdzinoši blīva nezāḷu veǵetācija. Arī 2013. gadā liels šīs sugas indivīdu daudzums bija novērojams parauglaukumos, kuru apsaimniekošanas režīms (diskota augsne, ziemas kvieši priekšaugs) veicināja ievērojami blīvāku nezāḷu veǵetāciju, taču citu sugu krasais dinamiskā blīvuma pieaugums neḷāva $A$. plebeja sasniegt vismaz subdominantu līmeni sugu sabiedrībā.

Var secināt, ka augsnes pamatapstrādes paṇēmiens un priekšaugi ietekmē skrejvaboḷu sugu sabiedrību kviešu sējumos. Tāpēc tai ir potenciāls būt par IAA indikatoru, taču tam vēl ir nepieciešami papildus pētījumi, jo arī citi vides faktori, piemēram, meteorologiskie apstākḷi var atstāt būtisku ietekmi uz dominējošo sugu īpatsvaru.

Skrejvaboḷu dinamiskā blīvuma atkarība no priekšauga un augsnes pamatapstrādes paṇēmiena fenolog̣iskā griezumā. Pētījumā no visa novēroto skrejvaboḷu sugu kopskaita tika izdalītas biežāk sastopamās sugas, kuru indivīdu īpatsvars vismaz vienā septiņu dienu pētījuma periodā sasniedza subdominantu vai augstāku līmeni parauglaukumos ar vismaz vienu augsnes pamatapstrādes un priekšauga kombināciju. Pavisam trīs gadu laikā šādiem kritērijiem atbilda 25 sugas (1. tab.). Desmit skrejvaboḷ sugu - Notiophilus aestuans, N. germinyi, Bembidion quadrimaculatum, Acupalpus meridianus, Platynus assimilis, Poecilus versicolor, Amara familiaris, A. ovata, A. similata un A. apricaria dinamiskos blīvumus neietekmēja neviens no abiem pētītajiem agroekologiskajiem faktoriem. No šīm sugām tikai $A$. meridianus atbilda biežāk sastopamo sugu kritērijiem visās trīs pētījuma sezonās, bet pārējās sugas šiem kritērijiem atbilda tikai vienā sezonā.

Divu sugu - B. guttula un $P$. niger dinamiskais blīvums salīdzinoši konsekventi reageeja uz agroekolog̣iskajiem faktoriem visās trīs sezonās. Tāpēc šīs sugas ir ieteicams izmantot par IAA indikatoriem kviešu sējumos. Abām sugām ir nepieciešami vidēji mitri vides apstākḷi, tāpēc to dinamiskais blīvums būtiski lielāks ir bijis parauglaukumos, kuru apsaimniekošanas režīms veicina blīvāku kviešu veǵetāciju.

B. guttula dinamisko blīvumu pozitīvi ir ietekmējusi gan augsnes aršana, gan priekšaugs rapsis. Izṇēmums bija 2014. gada sezonas sākums, kad vairāk šīs sugas indivīdu tika novērots diskotajos parauglaukumos, jo tajos pēc vasaras kviešu iesēšanas attīstìjās būtiski blīvāka nezāļu veǵetācija. Taču tās pašas sezonas otrajā dạ̦ā lielāks $B$. guttula dinamiskais blīvums atkal bija novērojams artajos parauglaukumos (6. att.). Lìdz ar to $B$. guttula dinamiskais blīvums ir izmantojams kā IAA pozitīvais indikators gan ziemas, gan vasaras kviešu 
sējumos. Piemērotākais sezonas periods, kad veikt šīs sugas novērojumus, ir jūlijs.

P. niger dinamisko blīvumu lielākoties ir ietekmējis priekšaugs. Š $̄ 1$ suga ir centusies izvairīties no parauglaukumiem, kuros nav veikta augu maina. Pirmajā pētījuma sezonā novērota arī augsnes aršanas pozitīva ietekme uz $P$. niger dinamisko blīvumu (7. att.). Tāpēc arī š̄ suga izmantojama par IAA pozitīvo indikatoru gan ziemas, gan vasaras kviešu sējumos. Piemērotākais sezonas periods, kad veikt $P$. niger novērojumus, ir jūlijs.

1. tabula

Biežāk sastopamās skrejvaboḷu sugas, tās ietekmējušie agroekoloğiskie faktori un to izmantojamība par IAA indikatoriem

Table 1

The most frequent ground beetle species, agro-ecological factors significantly affecting their frequency and availability to use them as indicators of IPM

\begin{tabular}{|c|c|c|}
\hline Suga / Species & 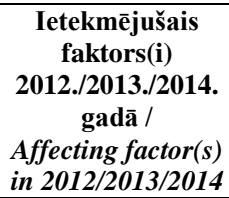 & $\begin{array}{c}\text { Izmantojamība par IAA indikatoru / } \\
\text { Availability as indicator of IPM }\end{array}$ \\
\hline Nebria brevicollis & $\mathrm{P} / \mathrm{P} /-$ & Izmantojama / Available \\
\hline Notiophilus aestuans & $-1-1-$ & Nav izmantojama / Not available \\
\hline Notiophilus germinyi & $-1-1-$ & Nav izmantojama / Not available \\
\hline Loricera pilicornis & $\mathrm{T} / \mathrm{T}, \mathrm{P} / \mathrm{T}$ & Nav izmantojama / Not available \\
\hline Carabus cancellatus & $-/ \mathrm{P} /-$ & Iespējami izmantojama / Possibly available \\
\hline $\begin{array}{l}\text { Bembidion } \\
\text { quadrimaculatum }\end{array}$ & $-1-1-$ & Nav izmantojama / Not available \\
\hline Bembidion lampros & $-/ \mathrm{P} /-$ & Nav izmantojama / Not available \\
\hline Bembidion properans & $\mathrm{T} / \mathrm{T} / \mathrm{T}$ & Iespējami izmantojama / Possibly available \\
\hline Bembidion guttula & T/T,P/T,P & Izmantojama / Available \\
\hline Bembidion obtusum & $\mathrm{T} / \mathrm{P} /-$ & Iespējami izmantojama / Possibly available \\
\hline Trechus quadristriatus & $\mathrm{T}, \mathrm{P} / \mathrm{T}, \mathrm{P} /-$ & Iespējami izmantojama / Possibly available \\
\hline Harpalus affinis & $-/ \mathrm{P} / \mathrm{P}$ & Iespējami izmantojama / Possibly available \\
\hline Harpalus rufipes & $-/ \mathrm{P} / \mathrm{P}$ & Nav izmantojama / Not available \\
\hline Acupalpus meridianus & $-1-1-$ & Nav izmantojama / Not available \\
\hline Platynus assimilis & $-1-1-$ & Nav izmantojama / Not available \\
\hline Anchomenus dorsalis & $-/ \mathrm{P} /-$ & Iespējami izmantojama / Possibly available \\
\hline Poecilus cupreus & $\mathrm{T} / \mathrm{P} / \mathrm{T}, \mathrm{P}$ & Nav izmantojama / Not available \\
\hline Poecilus versicolor & $-1-1-$ & Nav izmantojama / Not available \\
\hline Pterostichus melanarius & $\mathrm{P} / \mathrm{T}, \mathrm{P} / \mathrm{T}, \mathrm{P}$ & Iespējami izmantojama / Possibly available \\
\hline Pterostichus niger & $\mathrm{T}, \mathrm{P} / \mathrm{P} / \mathrm{P}$ & Izmantojama / Available \\
\hline Amara familiaris & $-1-/-$ & Nav izmantojama / Not available \\
\hline Amara ovata & $-1-1-$ & Nav izmantojama / Not available \\
\hline Amara similata & $-1-1-$ & Nav izmantojama / Not available \\
\hline Amara apricaria & $-1-1-$ & Nav izmantojama / Not available \\
\hline Amara plebeja & $\mathrm{T}, \mathrm{P} / \mathrm{T}, \mathrm{P} /-$ & Izmantojama / Available \\
\hline
\end{tabular}

$\mathrm{T}$ - augsnes pamatapstrādes pañēmiens, $\mathrm{P}$ - priekšaugs.

$T$ - main soil treatment; $P$ - pre-crop. 

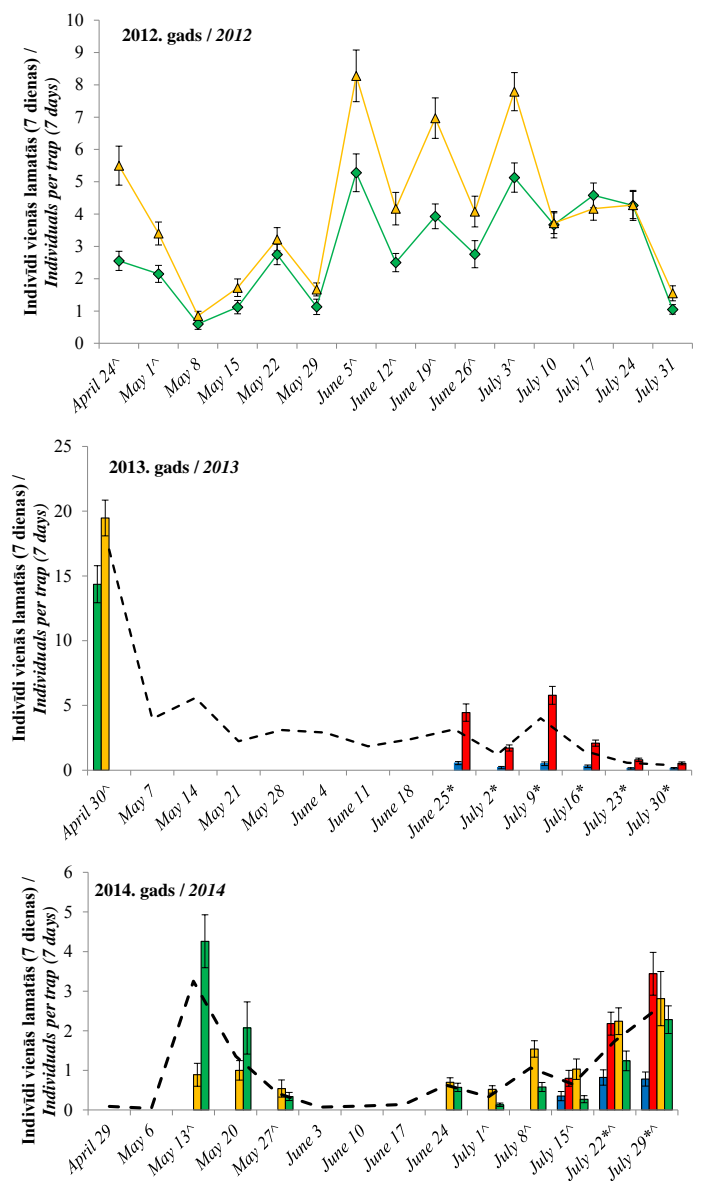

6. att. Vidējais Bembidion guttula dinamiskais blīvums kviešu parauglaukumos ar atšḳirīgu augsnes pamatapstrādes paṇēmienu 2012. gadā un atšḳirīgu augsnes pamatapstrādes paṇēmienu un dažādiem priekšaugiem 2013. un 2014. gadā - - - - vidējais dinamiskais blīvums; priekšaugi: — - ziemas kvieši, @ - rapsis; augsnes

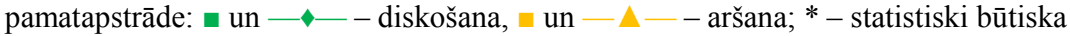
priekšauga ietekme, ${ }^{\wedge}$ - statistiski būtiska augsnes pamatapstrādes paṇēmiena ietekme (p $\leq 0.05)$.

Fig. 6. Mean activity density of Bembidion guttula in wheat sample plots with different main soil treatment in 2012 and in sample plots with different main soil treatment and pre-crops in 2013 and 2014

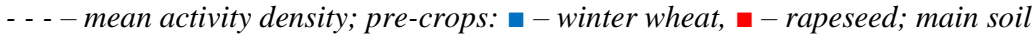
treatment: $\square$ and - - harrowing, and $-\Delta-$ - ploughing; * - statistically significant effect of pre-crop, ${ }^{\wedge}$ - statistically significant effect of main soil treatment $(p$ $\leq 0.05$ ). 

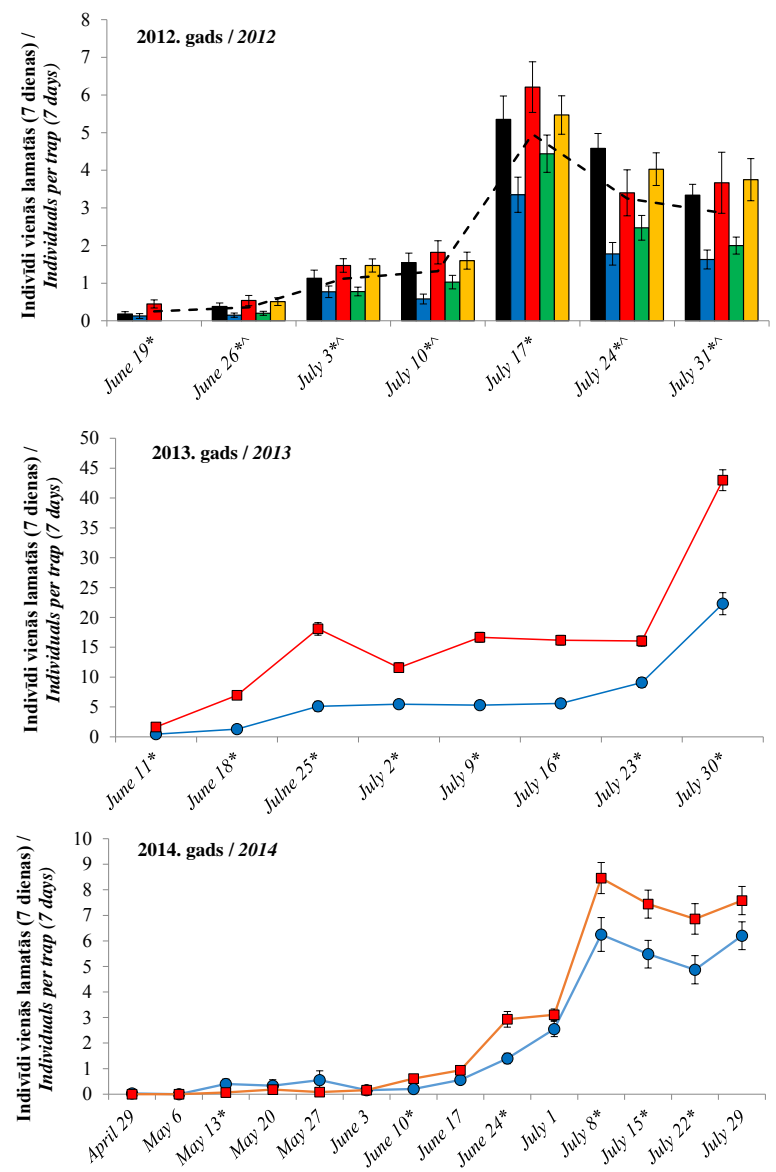

7. att. Vidējais Pterostichus niger dinamiskais blīvums kviešu parauglaukumos ar dažādiem priekšaugiem un atšḳirīgiem augsnes pamatapstrādes paṇēmieniem 2012. gadā un atšḳirīgiem priekšaugiem 2013. un 2014. gadā

- - - - vidējais dinamiskais blīvums; priekšaugi: - - vasaras kvieši, = un ——— - ziemas kvieši, = un - - - rapsis; augsnes pamatapstrāde: — - diskošana, = - aršana; * statistiski būtiska priekšauga ietekme, ${ }^{\wedge}$ - statistiski būtiska augsnes pamatapstrādes pan̄ēmiena ietekme $(\mathrm{p} \leq 0.05)$.

Fig. 7. Mean activity density of Pterostichus niger in wheat sample plots with different main soil treatment and pre-crops in 2012 and in sample plots with different pre-crops in 2013 and 2014

- - - mean activity density; pre-crops: - - spring wheat, $\mathbf{a}$ and - - - winter wheat, and - - - rapeseed; main soil treatment: - harrowing, - - ploughing; $*$ statistically significant effect of pre-crop, ${ }^{\wedge}$ - statistically significant effect of main soil treatment $(p \leq 0.05)$. 
Vēl divu sugu - Nebria brevicollis un A. plebeja - dinamiskos blīvumus var izmantot par IAA indikatoriem ziemas kviešu sējumos. N. brevicollis dinamiskais blīvums pozitīvi reaǵeja uz augu maiņu. Pirmajās divās pētījuma sezonās būtiski vairāk šīs sugas indivīdu tika novēroti parauglaukumos ar priekšaugu rapsi (8. att.). Trešajā sezonā, kad parauglaukumos bija iesēti vasaras kvieši, tajos tika novēroti tikai atsevišķi N. brevicollis indivīdi. Arī citviet Eiropā veiktos pētījumos ir konstatēts, ka šī suga gandrīz nemaz neapdzīvo vasarājus, jo, iespējams, to sējas laikā iet bojā $N$. brevicollis kāpuri, kuri ziemo uz lauka. Līdz ar to $N$. brevicollis ir izmantojama par pozitīvo IAA indikatoru ziemas kviešu sējumos. Piemērotākais audzēšanas sezonas periods, kad veikt sugas novērojumus, ir jūnijs.

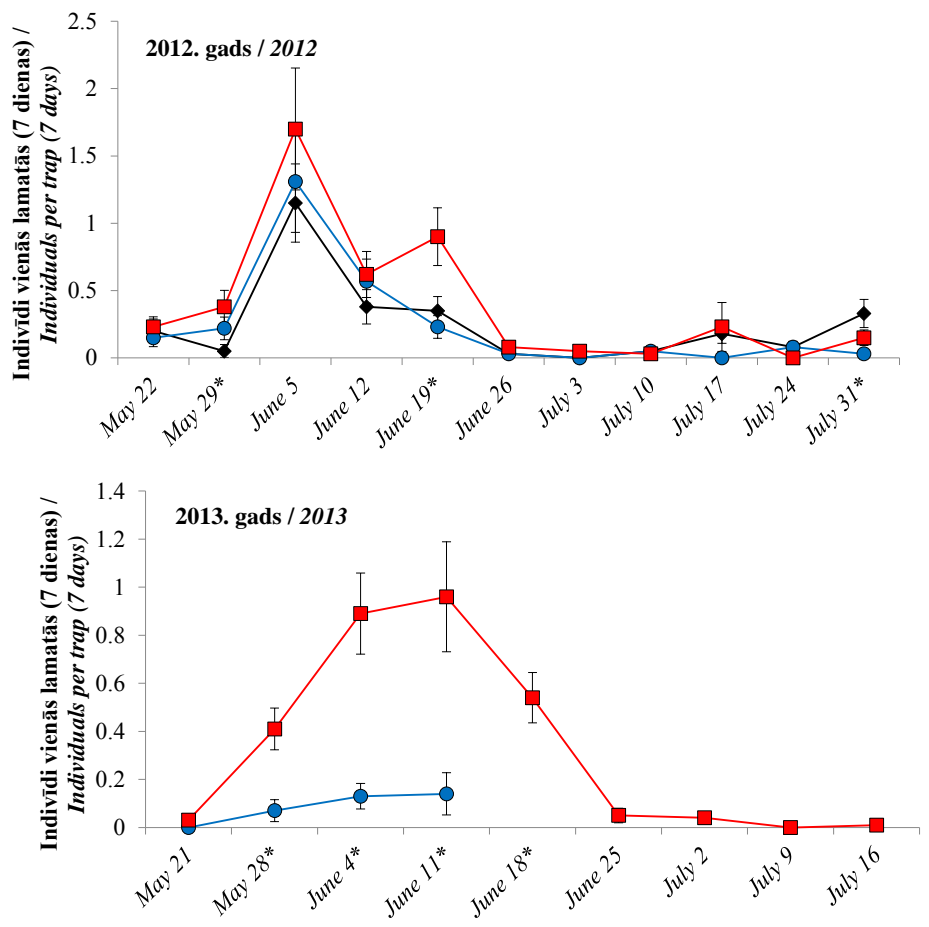

8. att. Vidējais Nebria brevicollis dinamiskais blīvums ziemas kviešu

parauglaukumos ar dažādiem priekšaugiem 2012. un 2013. gadā

Priekšaugi: ——- vasaras kvieši, ———-ziemas kvieši, ———- rapsis; * statistiski būtiska priekšauga ietekme, $(\mathrm{p} \leq 0.05)$.

Fig 8. Mean activity density of Nebria brevicollis in winter wheat sample plots with different pre-crops in 2012 and 2013

Pre-crops: - - spring wheat,-—- winter wheat, - - - rapeseed; *statistically significant effect of pre-crop $(p \leq 0.05)$. 
A. plebeja būtiski reaǵēja uz abu faktoru kombināciju. 2012. gadā būtiski lielāks tās dinamiskais blīvums bija diskotajos parauglaukumos ar vasaras kviešiem kā priekšaugu, bet 2013. gadā - diskotajos parauglaukumos ar ziemas kviešiem kā priekšaugu (9. att.). Abos pirmajos pētījuma gados šī suga deva priekšroku parauglaukumiem, kuru apsaimniekošanas režīms neatbilda IAA principiem un bija ḷāvis attīstīties salīdzinoši blīvai daudzgadīgu nezālu veǵetācijai. Trešajā pētījuma gadā š̄̄s nezāles tika iznīcinātas, izmantojot glifosātu saturošu herbicīdu, tāpēc arī A. plebeja parauglaukumos bija pārstāvēta ar atsevišķiem indivīdiem. Š ̄ suga ir izmantojama kā IAA negatīvais indikators ziemas kviešu sējumos. Piemērotākais audzēšanas sezonas periods, kad veikt novērojumus, ir jūlijs.

Vēl septinu sugu - Anchomenus dorsalis, Bembidion properans, B. obtusum, Carabus cancellatus, Harpalus affinis, P. melanarius un Trechus quadristriatus - dinamiskais blīvums būtiski reaǵēja uz pētītajiem agroekoloǵiskajiem faktoriem. Taču atsevišķos gadījumos reakcija nebija pilnībā izskaidrojama ar līdzšinējām zināšanām par šo sugu ekologiju. Tāpēc pagaidām šīs sugas var uzskatīt par potenciāliem IAA indikatoriem, par kuriem vēl nepieciešami papildus pētījumi. Gan A. dorsalis, gan $C$. cancellatus varētu būt pozitīvi augu maiņas indikatori, jo to dinamiskais blīvums bija būtiski lielāks parauglaukumos ar rapsi kā priekšaugu. Taču šāda sakarība tika novērota tikai otrajā pētījuma sezonā. Visticamāk, ka abas šīs sugas būtiski ietekmē vēl citi ekologiskie faktori, par kuriem pagaidām ir maz zināšanu. B. properans varētu būt piemērots negatīvais IAA indikators, ņemot vērā šīs sugas prasības pret vidi un vadoties pēc pētījuma otrās un trešās sezonas rezultātiem, kad šīs sugas dinamiskais blīvums bija būtiski lielāks diskotā augsnē. Taču pētījuma pirmajā sezonā š̄s sugas atkarība no augsnes pamatapstrādes pan̄ēmiena nebija tik skaidri izteikta, un tai bija pretēja tendence - lielāks dinamiskais blīvums artā augsnē. Iespējams, ka par IAA pozitīvo indikatoru ir izmantojama B. obtusum. Pirmajos divos pētījuma gados tika noskaidrots, ka šīs sugas dinamisko blīvumu būtiski var ietekmēt gan augsnes pamatapstrādes pan̄ēmiens, gan priekšaugi. Šì suga deva priekšroku parauglaukumiem ar artu augsni un/vai priekšaugu rapsi. Taču pētījuma trešajā gadā parauglaukumos tika novērots salīdzinoši neliels $B$. obtusum indivīdu skaits. Šì parādība pagaidām nav izskaidrojama, jo pētījuma parauglaukumi ir pirmā Baltijas valstu regiionā zināmā atradne, kur B. obtusum ir viena no dominējošām sugām kviešu agrocenozē. Arī Latvijas kaimiņvalstīs šñ suga ir reti sastopama, bet par vasarāju sēšanas ietekmi uz tās dinamisko blīvumu dati nav pieejami. Lìdz ar to nav iespējams pateikt, vai B. obtusum nelielais indivīdu blīvums vasaras kviešu cenozē ir saistīts ar vasarājiem specifiskiem agrotehniskajiem apstākḷiem, vai arī tam ir kāds cits iemesls, kas šo sugu varētu ietekmēt arī ziemas kviešu sējumos. Otrās un trešās pētījuma sezonas rezultāti parādīja, ka $H$. affinis varētu būt negatīvais IAA indikators, jo š̄̄ suga acīmredzami deva priekšroku parauglaukumiem, kuros netiek veikta augu maiņa. Taču pirmajā sezonā 

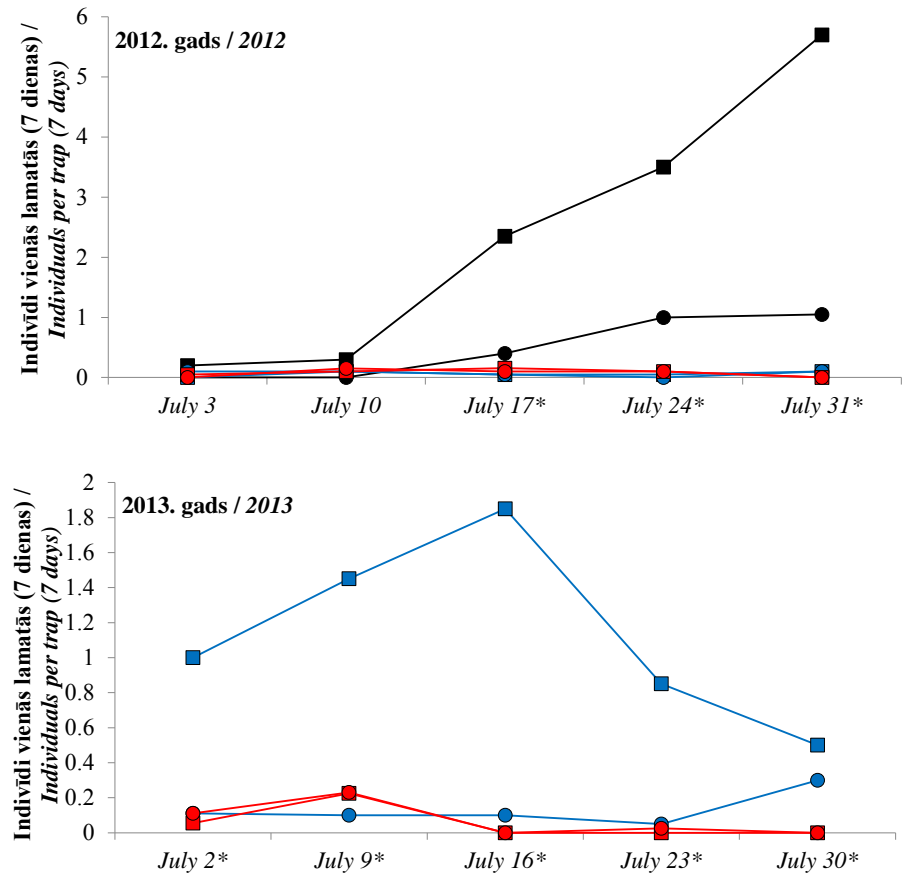

9. att. Vidējais Amara plebeja dinamiskais blīvums ziemas kviešu parauglaukumos ar dažādām priekšaugu un augsnes pamatapstrādes paṇēmienu kombinācijām 2012. un 2013. gadā

Faktoru kombinācijas: ——— - diskota augsne, vasaras kvieši priekšaugs, ——— - arta augsne, vasaras kvieši priekšaugs, _—— - diskota augsne, ziemas kvieši priekšaugs, - - - arta augsne, ziemas kvieši priekšaugs, ———- diskota augsne, rapsis priekšaugs, _- - arta augsne, rapsis priekšaugs; * - statistiski būtiska faktoru kombinācijas ietekme $(\mathrm{p} \leq 0.05)$.

Fig. 9. Mean activity density of Amara plebeja in winter wheat sample plots with different combinations of main soil treatment and pre-crop in 2012 and 2013 Combinations of factors: - - - harrowed soil, spring wheat as pre-crop, - - - ploughed soil, spring wheat as pre-crop, - - - harrowed soil, winter wheat as precrop, - - - ploughed soil, winter wheat as pre-crop, - - - harrowed soil, rapeseed as pre-crop, ——- ploughed soil, rapeseed as pre-crop; * - statistically significant effect of combination of factors $(p \leq 0.05)$.

statistiski būtiskas dinamiskā blīvuma atšķirības starp parauglaukumiem ar dažādiem priekšaugiem netika konstatētas, lai arī $H$. affinis dinamiskais blīvums bija pietiekami liels. Iespējams, ka šo parādību var izskaidrot ar pirmās sezonas salīdzinoši vēso un lietaino laiku, bet pagaidām tas ir tikai pieṇēmums. Potenciāli 
par IAA negatīvo indikatoru ir izmantojama arī $P$. melanarius. Divās pētījuma sezonās š̄ suga deva priekšroku parauglaukumiem bez augu maiņas un ar diskotu augsni. Taču vienā sezonā tās dinamiskais blīvums bija būtiski lielāks parauglaukumos ar rapsi kā priekšaugu. T. quadristriatus ir potenciāls pozitīvais IAA indikators. Pirmajās divās sezonās šīs sugas dinamiskais blīvums bija būtiski lielāks parauglaukumos ar artu augsni un rapsi kā priekšaugu. Taču trešajā sezonā šī suga parauglaukumos gandrīz nemaz nebija sastopama, un šis faktors nav izskaidrojams ar līdzšinējām zināšanām par sugas ekologiiju. Līdz ar to pagaidām nav piln̄̄gas pārliecības par to, ka augsnes pamatapstrādes paṇēmiens un priekšaugi ir vien̄̄gie ekoloǵiskie faktori, kuri varētu būtiski ietekmēt $T$. quadristriatus kviešu sējumos.

Četras skrejvaboḷu sugas, kuru dinamiskais blīvums būtiski reaǵēja uz pētītajiem agroekologiskajiem faktoriem, nevar izmantot par IAA indikatoriem. Tās ir Bembidion lampros, H. rufipes, L. pilicornis un P. cupreus. B. lampros dinamiskais blīvums uz pētītajiem faktoriem būtiski reaǵēja tikai otrajā pētījuma sezonā. Taču tad šī suga deva priekšroku parauglaukumiem ar rapsi kā priekšaugu, kas ir pretrunā ar līdzšinējām zināšanām par šîs sugas ekologiju. $H$. rufipes uz pētītajiem agroekoloǵiskajiem faktoriem vai nu nereaǵēja, vai arī š̄ reakcija bija pretrun̄̄ga vienas sezonas ietvaros - sezonas sākumā lielāks dinamiskais blīvums bija parauglaukumos ar vienu priekšaugu, turpinājumā - ar citu priekšaugu, bet beigās - atkal ar pirmo priekšaugu. Līdz ar to var secināt, ka augsnes pamatapstrādes pan̄ēmiens un augu maiṇa visticamāk nav limitējošie šīs sugas ietekmējošie faktori kviešu sējumos. L. pilicornis dinamiskais blīvums pirmajās divās sezonās bija būtiski lielāks diskotā augsnē, salīdzinot ar artu augsni, bet trešajā sezonā tika novērota pretēja sakarība. Turklāt otrajā pētījuma sezonā šīs sugas dinamisko blīvumu pozitīvi ietekmēja rapsis kā priekšaugs. Tas nozīmēe, ka vienas sezonas gaitā suga pozitīvi reaǵē uz augsnes pamatapstrādes paņēmienu, kurš nav uzskatāms par labu IAA praksi, un uz augu maiṇu, kas ir uzskatāma par labu IAA praksi. Līdzīga situācija tika novērota ar P. cupreus dinamisko blīvumu, kuru pozitīvi ietekmēja rapsis kā priekšaugs un diskota augsne.

Par IAA indikatoriem nav izmantojams skrejvaboḷu kopējais dinamiskais blīvums, jo tas uz augsnes pamatapstrādes paņēmieniem un priekšaugiem reaǵēja neviennozīmīgi. Pirmās sezonas gaitā atsevišksos pētījuma periodos tika konstatēta priekšauga būtiska ietekme uz skrejvaboḷu kopējo dinamisko blīvumu, taču ne visos šajos periodos viens un tas pats priekšaugs veicināja lielāko skrejvaboḷu aktivitāti. Otrā sezona bija vienīgā, kad visā tās laikā rapsis kā priekšaugs veicināja būtiski lielāku skrejvaboḷu kopējo dinamisko blīvumu, nekā ziemas kvieši kā priekšaugs. Trešajā sezonā būtisku ietekmi radīja augsnes pamatapstrādes pañēmiens, bet priekšaugi summāro dinamisko blīvumu neietekmēja. N̦emot vērā rezultātus par atsevišşu biežāk sastopamo sugu dinamiskā blìvuma atkarību no agroekologiskajiem faktoriem, jāsecina, ka summārā dinamiskā blīvuma konsekventa reakcija uz kādu no faktoriem drīzāk 
ir uzskatāma par nejaušību. Kopējais dinamiskais blīvums uz faktoru reaǵēs tāpat, kā reaǵēs dominējošās sugas ar nosacījumu, ka dominējošās sugas uz faktoriem reaǵe vienādi. Š̀ paša iemesla dēḷ par IAA indikatoru nav izmantojams dažādu skrejvaboḷu ekolog̣isko grupu summārais dinamiskais blīvums. Pētījuma ietvaros tika analizēta abu agroekologisko faktoru ietekme uz mazajām skrejvabolēm (k,ermeņa garums līdz $5 \mathrm{~mm}$ ) un vidējām un lielajām skrejvabolēm (ķermeņa garums virs $5 \mathrm{~mm}$ ) 2012. gadā. Tika konstatēts, ka mazo skrejvaboḷu kopējais dinamiskais blīvums ir būtiski lielāks artos parauglaukumos, bet vidējo un lielo skrejvaboḷu - diskotajos parauglaukumos. Taču, kad tika konstatēts, ka vienas un tās pašas ekoloǵiskās grupas sugas uz augsnes pamatapstrādes paņēmieniem un priekšaugiem reaǵē atškirīịi, skrejvaboḷu ekoloǵisko grupu kopējā dinamiskā blīvuma analizēšana netika turpināta.

Kviešu sējumu augsnes pamatapstrādes paṇēmiena un priekšaugu ietekme uz skrejvaboḷu sugu daudzveidību. Visās pētījuma sezonās parauglaukumos tika konstatēta augsnes pamatapstrādes pan̄ēmiena un priekšaugu ietekme uz skrejvaboḷu sugu daudzveidību. Taču ne vienmēr novērotā ietekme bija vienāda visos trīs gados. 2012. gadā vislielākā sugu daudzveidība tika novērota parauglaukumos ar divām abu faktoru kombinācijām: arta augsne un rapsis priekšaugs, kas veicina blīvāku kviešu veǵetāciju (1), diskota augsne un vasaras kvieši priekšaugs, kas veicināja vājāku kviešu veǵetāciju, kuru kompensēja blīvāka nezāḷu veǵetācija (2). Abos gadījumos parauglaukumu veǵetācija skrejvabolēm ir veicinājusi lielākus paslēptuvju un barības resursus, piesaistot fitofăgos bezmugurkaulniekus vai veicinot nezāḷu sēklu klātbūtni. Pārējos parauglaukumos sugu daudzveidība bija būtiski zemāka. Nav izskaidrojams, kāpēc viszemākā sugu daudzveidība tika konstatēta diskotajos parauglaukumos ar rapsi kā priekšaugu (10. att.).

2013. gadā lielāku skrejvaboḷu sugu daudzveidību visos parauglaukumos veicināja rapsis kā priekšaugs. Taču statistiski būtiska atšķirība tika novērota tikai artajos parauglaukumos. Diskota augsne kombinācijā ar ziemas kviešiem kā priekšaugu, pateicoties blīvajai nezāḷu veǵetācijai, veicināja līdzvērtīgu skrejvaboḷu sugu daudzveidību, kā priekšaugs rapsis neatkarīgi no augsnes apstrādes. Arī augsnes pamatapstrādes paņēmiens, neatkarīgi no priekšaugiem, būtiski ietekmēja sugu daudzveidību. Pētījuma otrajā gadā diskotā augsnē tika konstatēta lielāka skrejvaboḷu daudzveidība nekā artā augsnē (11. att.). Tas skaidrojams ar to, ka 2013. gadā nezāḷu ierobežošana ar herbicīdiem nebija tik sekmīga kā gadu iepriekš. Visos diskotajos parauglaukumos pēc herbicīda smidzināšanas nezāḷu blīvums nesamazinājās, bet vairākos parauglaukumos tas ievērojami pieauga. 


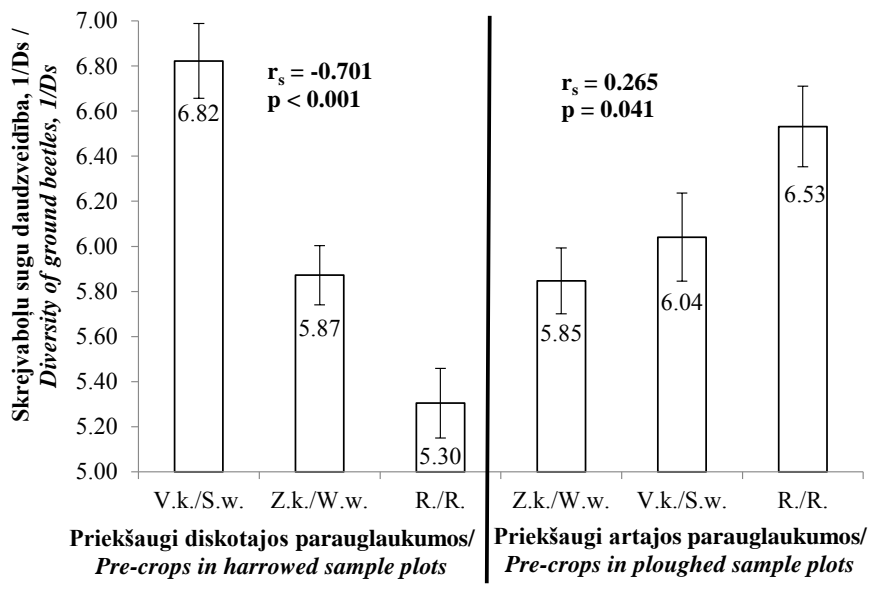

10. att. Skrejvaboḷu sugu daudzveidība ziemas kviešu parauglaukumos ar atšķirīgiem augsnes pamatapstrādes paṇēmieniem un priekšaugiem 2012. gadā Priekšaugi: V.k. - vasaras kvieši, Z.k. - ziemas kvieši, R. - rapsis.

Fig. 10. Diversity of ground beetles in winter wheat sample plots with different main soil treatments and pre-crops in 2012

Pre-crops: S.w. - spring wheat, W.w. - winter wheat, R. - rapeseed).

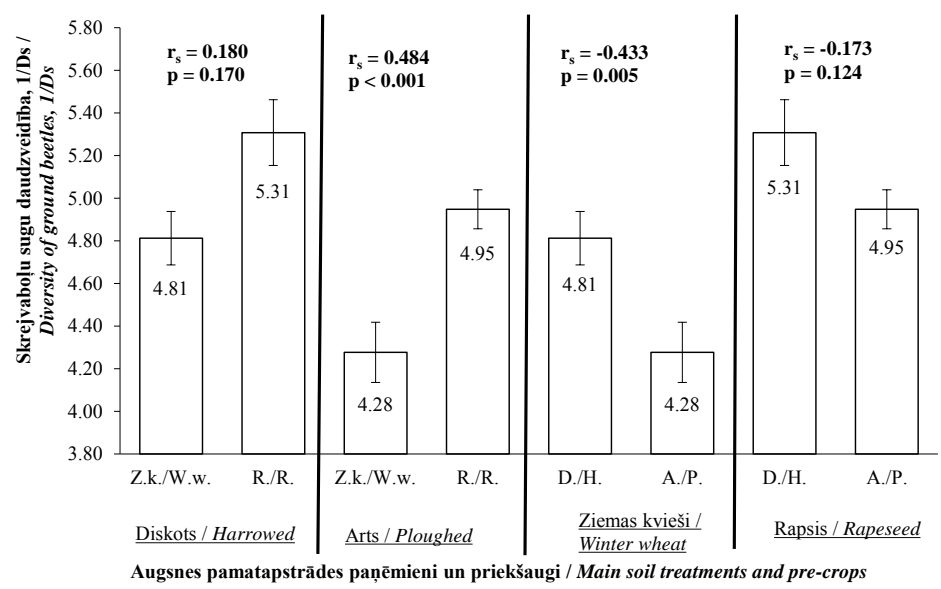

11. att. Skrejvaboḷu sugu daudzveidība ziemas kviešu parauglaukumos ar atšķirīgiem augsnes pamatapstrādes paṇēmieniem un priekšaugiem 2013. gadā Priekšaugi: Z.k. - ziemas kvieši, R. - rapsis; augsnes pamatapstrādes paṇēmieni: D. diskošana, A - aršana.

Fig. 11. Diversity of ground beetles in winter wheat sample plots with different main soil treatments and pre-crops in 2013

Pre-crops: W.w. - winter wheat, R. - rapeseed; main soil treatments: H. - harrowing, P. - ploughing. 
Trešajā pētījuma sezonā parauglaukumos tika īstenota intensīvāka nezāl̨u ierobežošana. Pirms vasaras kviešu sējas, izmantojot glifosātu saturošu preparātu, tika iznīcināta daudzgadīgo nezāḷ veǵetācija, kura vislabāk bija attīstījusies parauglaukumos bez augu maiņas un ar diskotu augsni. Arī audzēšanas sezonas laikā herbicīdu smidzināšana bija efektīva. Pēc tās nezāḷu blīvums visos parauglaukumos bija līdzīgi neliels. Tā rezultātā vislielākā skrejvaboḷu sugu daudzveid̄̄ba tika novērota parauglaukumos ar rapsi kā priekšaugu, bet augsnes pamatapstrādes paņēmienam šajos parauglaukumos nebija būtiskas ietekmes. Parauglaukumos ar ziemas kviešiem kā priekšaugu būtiski lielāka skrejvaboḷu daudzveid̄̄ba tika konstatēta, ja augsne bija arta (12. att.).

Skrejvaboḷu sugu daudzveidība varētu būt piemērotāks IAA indikators nekā sugu sabiedrība. Pētījums apliecināja, ka starp parauglaukumiem ar dažādu apsaimniekošanas režīmu pastāvēja būtiskas skrejvaboḷu sugu daudzveidības atšķirības. Taču pagaidām pastāv viens nozīmīgs kavēklis sugu daudzveidības izmantošanai par indikatoru. Pirmie divi pētījuma gadi apliecināja, ka augstākā sugu daudzveidība ir novērojama gan parauglaukumos, kuri tiek apsaimniekoti atbilstoši labai IAA praksei, gan parauglaukumos, kuru apsaimniekošana neatbilst IAA principiem, bet augsto skrejvaboḷu sugu daudzveidību tajos nodrošina ilgstoši pastāvējusī nezāḷ veǵetācija. Šĩ iemesla dēl nepieciešami papildus pētījumi par skrejvaboḷu sugu daudzveidību kviešu sējumos ar atškirīīgu augsnes pamatapstrādes pan̄ēmienu un dažādiem priekšaugiem. Viens no papildus pētījumu virzieniem varētu būt sugu daudzveidības analīze fenologiskā griezumā. Šādi varētu pārbaudīt, vai atsevišķos veǵetācijas sezonas periodos kviešu sējumos, kuri tiek apsaimniekoti atbilstoši IAA principiem, skrejvaboḷu sugu daudzveidība ir būtiski atšķirīga no citiem sējumiem, kuros laba IAA prakse netiek īstenota, bet nezāḷ ierobežošanas sekmes tajos neatstāj ietekmi uz skrejvabolēm. 


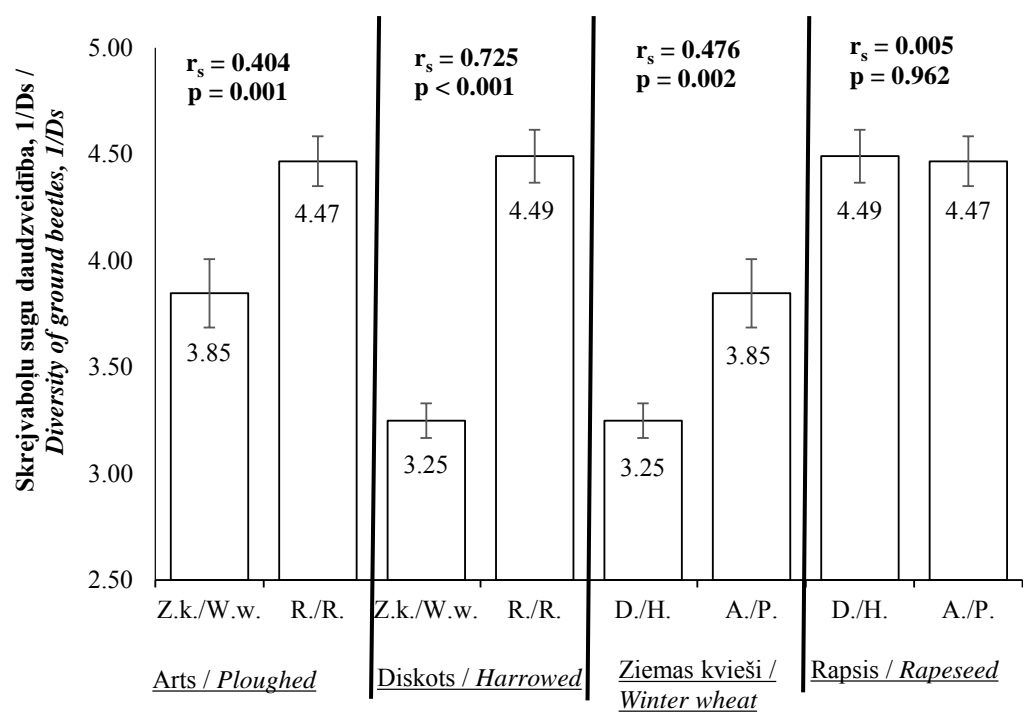

Augsnes pamatapstrādes paṇēmieni un priekšaugi / Main soil treatments and pre-crops

12. att. Skrejvaboḷu sugu daudzveidība vasaras kviešu parauglaukumos ar atšķirīgiem augsnes pamatapstrādes paṇēmieniem un priekšaugiem 2014. gadā Priekšaugi: Z.k. - ziemas kvieši, R. - rapsis; augsnes pamatapstrādes paṇēmieni: D. diskošana, A - aršana.

Fig. 12. Diversity of ground beetles in spring wheat sample plots with different main soil treatments and pre-crops in 2014

Pre-crops: W.w. - winter wheat, $R$. - rapeseed; main soil treatments: H. - harrowing, P. - ploughing. 


\section{Secinājumi}

1. Pētītajos kviešu sējumos skrejvaboḷu sugu sabiedrību veidoja 75 sugas, no kurām dominējošākās bija Bembidion guttula, Loricera pilicornis, Harpalus rufipes, Poecilus cupreus, Pterostichus melanarius un P. niger.

2. Atšķirīgi augsnes pamatapstrādes paṇēmieni un dažādi priekšaugi kviešu sējumos ietekmēja skrejvaboḷu sugu sabiedrības. Atkarībā no agroekologisko faktoru izpausmes sugu īpatsvars varēja būtiski mainīties, taču galvenās dominējošās sugas lielākoties saglabājās vienas un tās pašas neatkarīgi no kviešu sējumu apsaimniekošanas režīma.

3. Viens vai abi egroekologiskie faktori būtiski ietekmēja dinamisko blīvumu piecpadsmit skrejvaboḷu sugām: Amara plebeja, Anchomenus dorsalis, $B$. guttula, B. lampros, B. properans, B. obtusum, Carabus cancellatus, Harpalus affinis, H. rufipes, L. pilicornis, Nebria brevicollis, P. cupreus, $P$. melanarius, $P$. niger un Trechus quadristriatus. Abu faktoru kombinācija ietekmēja vienas sugas - A. plebeja - dinamisko blīvumu.

4. Augsnes pamatapstrādes paņēmiens un priekšaugi kviešu sējumos būtiski ietekmēja skrejvaboḷu sugu daudzveidību. Lielāku sugu daudzveidību veicināja divi kviešu sējumu apsaimniekošanas režīmi: augsnes aršana un priekšaugs rapsis (1), augsnes diskošana un augu maiņas neveikšana (2). Otrā apsaimniekošanas režīma gadījumā augsta skrejvaboḷu sugu daudzveidība bija novērojama, ja sējumos pietiekami sekmīgi netika ierobežota nezāḷ veǵetācija.

5. Četru sugu - B. guttula, P. niger, A. plebeja un N. brevicollis - dinamiskos blīvumus ir iespējams izmantot par IAA indikatoriem kviešu sējumos. $A$. plebeja un N. brevicollis izmantojamas par indikatoriem tikai ziemas kviešu sējumos, bet pārējās divas sugas izmantojamas gan ziemas, gan vasaras kviešu sējumos.

6. Potenciāli par IAA indikatoriem kviešu sējumos varētu izmantot skrejvaboḷu sugu sabiedrību, skrejvaboḷu sugu daudzveidības indeksu un septinu sugu - A. dorsalis, B. obtusum, B. properans, $C$. cancellatus, $H$. affinis, $P$. melanarius un T. quadristriatus - dinamiskos blīvumus. Sugu daudzveidības indekss varētu būt piemērotāks indikators nekā sugu sabiedrība. Taču par šiem parametriem nepieciešami papildus pētījumi.

7. Skrejvaboḷu summārais dinamiskais blīvums, dažādu skrejvaboḷu sugu ekologisko grupu summārais dinamiskais blīvums, kā arī četru sugu $-B$. lampros, $H$. rufipes, $P$. cupreus un $L$. pilicornis - dinamiskie blīvumi nav izmantojami par IAA indikatoriem kviešu sējumos. 


\section{Pētijuma aprobācija}

\section{Approbation of the scientific work}

Zinātniskie raksti, kas indeksēti Scopus un/vai Web of Science datu bāzēs/ Articles indexed in Scopus and/or Web of Science data bases

1. Gailis J., Turka I. (2013). Discussion on ground beetles and rove beetles as indicators of sustainable agriculture in Latvia: Review. Proceedings of Annual 19th International Scientific Conference 'Research for Rural Development 2013', Vol. 1, p. 56-62.

2. Gailis J., Turka I. (2014). The diversity and structure of ground beetles (Coleoptera: Carabidae) assemblages in differently managed winter wheat fields. Baltic Journal of Coleopterology, Vol. 14, No. 1, p. 33-46.

3. Gailis J., Turka I., Ausmane M. (2017). Soil tillage and crop rotation differently affect biodiversity and species assemblage of ground beetles inhabiting winter wheat fields. Agronomy Research, Vol. 15, No. 1, p. 94111.

4. Gailis J., Turka I., Ausmane M. (2017). The most frequent ground beetles (Coleoptera, Carabidae) are differently affected by main soil treatment and crop rotation in winter wheat fields. Acta Biologica Universitatis Daugavpiliensis, Vol. 17, No. 1, p. 29-52.

Citi zinātniskie raksti/ Other scientific articles

1. Gailis J., Turka I. (2014). Preliminary research on ground beetles (Coleoptera: Carabidae) as indicators of integrated pest management in winter wheat. Proceedings of the $55^{\text {th }}$ International Scientific Conference of Daugavpils University, p. 13-20.

2. Gailis J., Turka I. (2014). Bembidion gints skrejvaboḷu (Coleoptera: Carabidae) fenologija atšķirīgi apsaimniekotos ziemas kviešu sējumos. Ražas svētki "Vecauce - 2014": Lauksaimniecības zinātne jaunajā plānošanas periodā. Zinātniskā semināra rakstu krājums. 20.-23. lpp.

Populārzinātniski raksti/ Popular science articles

1. Gailis J. (2015). Skrejvaboles - integrētās augu aizsardzības elementi laukkopībā. Saimnieks LV, Nr. 8 (134), 46.-49. lpp. 
1. Gailis J., Turka I. (2012). Ground beetles (Coleoptera: Carabidae) and row beetles (Coleoptera: Staphylinidae) as indicators of integrated pest management in winter wheat fields. NJF Report, Vol. 8, No. 7, p. 101-102.

2. Gailis J., Turka I. (2013). Preliminary Research on Ground Beetles (Coleoptera: Carabidae) as Indicators of Integrated Pest Management in Winter Wheat. Abstracts of the $55^{\text {th }}$ International Scientific Conference of Daugavpils University, p. 26.

3. Gailis J., Turka I. 2014. The Dominance Structure of Ground Beetles (Coleoptera: Carabidae) Within Differently Managed Winter Wheat Fields. $L U$ 72. konferences tēzes.(http://priede.bf.lu.lv/konf/apsek/zoo/2014/Bezmugurkaulnieki/Gaili s_Turka_Carabidae.pdf). [Skatīts 2017. gada 13. septembrī].

4. Gailis J., Turka I. (2014). The Biodiversity of Ground Beetles (Coleoptera: Carabidae) in Differently Managed Winter Wheat Fields. Abstracts of the $56^{\text {th }}$ International Scientific Conference of Daugavpils University, p. 32.

5. Gailis. J., Turka I. (2015). The assessment of Previously Unapplied field Method for Research on Ground Beetles as Indicators of Integrated Pest Management. Proceedings of the $25^{\text {th }}$ NJF Congress (Riga, Latvia, $16^{\text {th }}-$ $18^{\text {th }}$ of June, 2015), p. 60 (indexed in Scopus).

6. Gailis J., Turka I. (2015). The Heterogeneity of Landscape Enhances Species Richness of Ground Beetles (Coleoptera: Carabidae) in Wheat Fields. NJF Report, Vol. 11, No 2, p. 39.

7. Gailis J., Turka I. 2016. The Phenology of Ground Beetles (Carabidae) in Differently Managed Winter Wheat Fields. 20 th Baltic Agronomy Forum, Book of Abstracts, p. 26.

8. Gailis J., Turka I. (2017). Phenological research on ground beetles (Coleoptera: Carabidae) inhabiting differently tilled and pre-cropped winter wheat fields. $9^{\text {th }}$ International Conference on Biodiversity Research, Book of Abstracts, p. 38-39.

Referāti starptautiskās konferencēs/ Oral and poster presentations in international conferences

1. Gailis J., Turka I. (2012). Ground beetles (Coleoptera: Carabidae) and row beetles (Coleoptera: Staphylinidae) as indicators of integrated pest management in winter wheat fields. NJF Seminar 457 'Sustainable Agriculture in The Baltic Sea Region with focus on climate change'. Uppsala, Sweden (30-31 October 2012).

2. Gailis J., Turka I. (2013). Preliminary Research on Ground Beetles (Coleoptera: Carabidae) as Indicators of Integrated Pest Management in 
Winter Wheat. The $55^{\text {th }}$ International Scientific Conference of Daugavpils University. Daugavpils, Latvia (April 10-12, 2013).

3. Gailis J., Turka I. (2013). Discussion on Ground Beetles and Rove Beetles as Indicators of Sustainable Agriculture in Latvia. Annual $19^{\text {th }}$ International Scientific Conference 'Research for Rural Development 2013'. Jelgava, Latvia (15-17 May 2013).

4. Gailis J., Turka I. (2014). The Biodiversity of Ground Beetles (Coleoptera: Carabidae) in Differently Managed Winter Wheat Fields. The $56^{\text {th }}$ International Scientific Conference of Daugavpils University. Daugavpils, Latvia (9-11April 2014).

5. Gailis J., Turka I. (2015). The assessment of Previously Unapplied field Method for Research on Ground Beetles as Indicators of Integrated Pest Management. 25th NJF Congress 'Nordic View to Sustainable Rural Development'. Rīga, Latvia (16-18 June 2015).

6. Gailis J., Turka I. (2015). The Heterogenity of Landscape Enhances Species Richness of Ground Beetles (Coleoptera: Carabidae) in Wheat Fields. NJF Seminar 484 'Biodiversity Based Integrated Pest Management in Field Crops'. Wiks Castle, Uppsala, Sweden (3 September 2015).

7. Gailis J., Turka I. (2016). The Phenology of Ground Beetles (Carabidae) in Differently Managed Winter Wheat Fields. 20 $0^{\text {th }}$ Baltic Agronomy Forum. Jelgava, Latvia (7-8 July 2016).

8. Gailis J., Turka I. (2017). Phenological research on ground beetles (Coleoptera: Carabidae) inhabiting differently tilled and pre-cropped winter wheat fields. $9^{\text {th }}$ International Conference on Biodiversity Research. Daugavpils, Latvia (26-28 April 2017).

Referāti vietēja mēroga konferencēs/ Oral and poster presentations in local conferences

1. Gailis J., Turka I. (2013). Integrētās augu aizsardzības metodes elementu skrejvaboḷu (Coleoptera: Carabidae) un īsspārṇu (Coleoptera: Staphylinidae) - pētījumi ziemas kviešu sējumos. Zinātniski praktiskā konference „Lauksaimniecības zinātne veiksmīgai saimniekošanai”. Jelgava, Latvija (21.02.-22.02.2013.).

2. Gailis J., Turka I. (2014). Skrejvaboḷu (Coleoptera: Carabidae) dominances struktūra atškirīgi apsaimniekotos ziemas kviešu laukos. Latvijas Universitātes 72. zinātniskā konference. Rīga, Latvija (2014. gada 31. janvāris).

3. Gailis J., Turka I. (2014). Skrejvaboles (Coleoptera: Carabidae) - integrētās augu aizsardzības elementi. Zinātnisks seminārs , Ražas svētki „,Vecauce 2014": Lauksaimniecības zinātne jaunajā plānošanas periodā". Vecauce, Latvija (2014. gada 6. novembris). 


\section{Introduction}

Integrated Pest Management is a practical tool allowing to significantly decrease the usage of chemicals, but at the same time maintaining a high crop productivity. Thus, it is possible to significantly decrease the agricultural load on environment. Though IPM was started already at the beginning of the 20th century and its first definition was published in 1959 (Stern, Smith, van den Bosch et al., 1959), in practice it has been implemented quite slowly and ponderously. In Latvia, according to the Law on Plant Protection, implementation of IPM in farms is mandatory since January 1 2014. This requirement applies to professional users of plant protection products using protection products of the second registration class or who use services provided by professional plant protection products' users.

One of the IPM elements is natural enemies of various organisms harmful to crops, including ground beetles (Carabidae). Beetles of this family inhabit all terrestrial ecosystems, are ecologically related to topsoil and are economically significant suppressor of harmful invertebrates and weeds in different agrocenoses. Studies in Europe and elsewhere in the world have shown that ground beetles - activity density of their populations, species diversity, number of species and other parameters - react significantly to various changes of environmental factors, including agrotechnical activities in agrocenoses. Thus, it can be considered that ground beetles are able to indicate different IPM events, as IPM is a complex of various purposeful agronomic activities.

Topicality of the Doctoral Thesis. The necessity to determine IPM indicators derives from a number of political documents. OECD, whose member state since 2016 is also Latvia, has agreed on this on an international level. This organization has defined two IPM indicator groups: uptake indicators and impact indicators. Usage ratio of biological methods for the control of harmful species have been mentioned as one of the IPM intensity indicators. However, IPM impact indicators are various environmental parameters, including biological diversity indicators. Essential features determined for potential indicators are simplicity (understandable), comparability, low costs, related to IPM definition, applicable to all countries, etc. At present, IPM indicators have not been developed yet; however, the main target of OECD is to develop impact indicators that should include terrestrial biological diversity indicators. Ground beetles as IPM elements and a part of biological diversity can be used as both IPM intensity indicators and impact indicators. Moreover, they possess most characteristics determined for the indicators.

In Latvia, the development of IPM indicators is indirectly determined in the Order No. 146 'On the action plan for sustainable use of plant protection products for the period 2013-2015' issued on 12.04 .2013 by the Cabinet of Ministers of the Republic of Latvia. This document provides determination of risk indicators for the usage of plant protection products. As the main objective 
of IPM is the decrease of risk caused by plant protection products, IPM indicators might be used as low risk plant protection products indicators. Such indicators have not been developed neither in Latvia nor in Europe, therefore it is suggested in the Order issued by the Cabinet of Ministers to use biological diversity indicators as determined in Regulations No. 175 'Regulations on National Environmental Indicators' issued by the Cabinet of Ministers of the Republic of Latvia on 24.02.2009. From the indicators mentioned in the list sustainable use of plant protection products is better characterized by rural bird index and amphibian species index. However, these indicators depend not only on plant protection products but also on general load on environment created by agriculture. As ground beetles in agrocenoses react specifically on the usage of plant protection products, their structure of species assemblage, species diversity and other parameters might potentially be a better indicator of the sustainable use of pesticides.

The novelty of the Doctoral Thesis. IPM indicators have not been developed neither in Latvia, nor elsewhere in Europe. Therefore, for the first time within the framework of this research IPM indicators will be determined for wheat sowings.

Hypothesis of the Doctoral Thesis. Ground beetles can be used as IPM indicators in wheat sowings.

The objective of the Doctoral Thesis. To determine how and how significantly do various parameters related to ground beetles - species assemblage, activity density and species diversity - react on different main soil treatment methods and different crop rotation regimes in wheat sowings.

Soil treatment and crop rotation are among the most important IPM elements in agriculture, therefore these agro-ecological factors were chosen for the study. Wheat sowings as research environment were chosen, as there is no need to use insecticides in these agrocenoses in Latvian conditions. Thus, wheat sowings are a suitable environment for this study, as the obtained data is not directly affected by the usage of plant protection products.

\section{Tasks of the Doctoral Thesis:}

1) To calculate ground beetle dominance structures and species diversity, as well as to determine activity densities of species populations in differently managed sample plots;

2) To determine how significantly are the parameters related to ground beetles affected by the different main soil treatment methods and winter wheat pre-crops;

3) To determine the potential IPM indicators in wheat sowings.

\section{Provable Theses:}

1) Different main soil treatment methods and pre-crops significantly influence species assemblage of ground beetles in wheat sowings;

2) Different main soil treatment methods and pre-crops significantly influence the total ground beetle activity density, the activity density 
of the most commonly occurring species and the activity density of species ecological groups in wheat sowings;

3) Different main soil treatment techniques and pre-crops significantly influence ground beetle species diversity in wheat sowings.

Doctoral study was carried out within the framework of two projects:

1) State Research program project 'Sustainable Use of Local Agricultural Resources for the Development of High Nutritive Value Food Products' sub-project 3.1. 'Sustainable Use of Soil as the Main Resource for the Production of Safe and Qualitative Food and Feed from the Main Agricultural Crops' (2012-2013).

2) State Research program 'Agricultural Resources for Sustainable Production of Qualitative and Healthy Foods in Latvia' project 'Sustainable use of soil resources and abatement of fertilisation risks' (since 2014).

Approbation of research results. The results of this research have been presented in seven reports in international scientific conferences and in three reports in Latvian scientific conferences. Four articles have been published in scientific magazines, indexed in Scopus or Thomson Reuters Web of Science databases, two articles in other scientific magazines and one article in popular science magazine, as well as theses of eight scientific conferences. 


\section{Research conditions and methodology}

Description of research location and conditions. Research was carried out during 2012-2014 at stationary of agronomic trials located in Jelgava region Platone municipality, LLU Research and Study Farm (RSF) 'Pēterlauki' near Poki village, $14 \mathrm{~km}$ South of Jelgava $\left(56^{\circ} 30^{\prime} 39.38^{\prime \prime} \mathrm{N}\right.$; 234ㄴ $30.15^{\prime}$ 'E). Stationary of Agronomic trials was established in 2009 for different researches of good agricultural practice in the most popular crop sowings in Latvia. Stationary consisted of 24 rectangular sample plot grid. The size of each sample plot was $30 \times 85 \mathrm{~m}$, but area 0.25 ha. Sample plot grid was enclosed by conventionally treated arable land, but $30 \mathrm{~m}$ to South a narrow $(35 \times 510 \mathrm{~m})$ forest zone was located, made up of about 60 years old deciduous wood that developed on former agricultural land. The nearest buildings were located $120 \mathrm{~m}$ to West from the research sample plot grid. Sample plots were separated from both each other and from surrounding fields with $2.5 \mathrm{~m}$ wide land zones covered with wild herbaceous plant vegetation. Since the establishment of the stationary all activities, e.g., soil treatment, field crop sowing, usage of fertilizers and pesticides, harvesting, etc., was carried out in accordance with the principles of conventional agricultural practice, using a traditional agricultural techniques as it would have been done in any commercial field.

The upper layer of the research land was Endogleyic Calcisol (GLu) with $\mathrm{pH} \mathrm{KCl} 6.8$ and low humus content $-20 \mathrm{~g} \mathrm{~kg}^{-1}$. Two different main soil treatment methods are used to all sample plots. Since the establishment of the grid, 12 sample plots were ploughed with mould-board plough every autumn. Depth of ploughing $0.22-0.23 \mathrm{~m}$. In other 12 sample plots, the topsoil was not overturned. Their main soil treatment was harrowing at a $0.10-0.11 \mathrm{~m}$ depth using disc harrows (hereinafter - harrowing). Other soil treatment activities of the sample plots were carried out according to traditional agricultural practice as in any other commercial field.

In 2012 and 2013, the research was carried out in six ploughed and six harrowed sample plots sown with winter wheat (variety 'Zentos'). However, in 2014 spring wheat (variety 'Taifun') was sown in the 12 sample plots, as winter wheat was destroyed by frost during winter 2013/2014. Other sample plots of the stationary were sown with other field crops each year. Thus, during each research year, several agroecological two-factor combinations formed: main soil treatment type and pre-crop. Spring wheat, winter wheat and spring rapeseed were pre-crops for winter wheat in every two harrowed and ploughed sample plots in 2012. Thus, six both-factor combinations formed in this vegetation season. Four both-factor combinations formed in 2013, when spring rapeseed was a pre-crop for winter wheat in four ploughed and four harrowed sample plots, but in two ploughed and two harrowed sample plots - it was winter wheat. Five both-factor combinations formed in 2014, when winter wheat and spring and winter rapeseed were pre-crops in spring wheat sample plots. In this study, the 
results of 2014 are analysed within the frameworks of four combinations: two ploughed and two harrowed sample plots with winter wheat as a pre-crop, as well as four ploughed and four harrowed sample plots with rapeseed as a pre-crop (Fig.1).

After harvesting, straw and other plant remains were left on sample plots as fertilizer, however, each year mineral fertilizers were used for soil fertilization. Each year, herbicides, fungicides and growth regulators registered in Latvia were used in the study sample plots sown with wheat. Insecticides and other plant protection products were not used to control undesirable organisms of wildlife. All plant protection products were used if necessary, when determined by the results of weed and plant disease monitoring.

Red dead-nettle (Lamium purpureum), wall speedwell (Veronica arvensis), cleavers (Galium aparine) and knotgrass (Polygonum aviculare) were the most commonly detected weed species in all sample plots. However, in the harrowed sample plots, where wheat followed wheat each year, also loose silkybent (Apera spica-venti) was among the most dominating weed species. Total weed density in sample plots was twice assessed during each study year. The first accounting was carried out during the first decade of May in 2012 and 2013, on 3 rd and 10th May, respectively. However, the first weed accounting of 2014 was carried out during the third decade of May - on May 22. The second weed accounting was carried out during the first decade of July in 2012 and 2013, on 8th and 9th July, respectively, but in 2014 - during the 3rd decade of July, on July 24. Each year, approximately one week after the first weed accounting, weed control using herbicides was carried out. However, in 2014, sample plots were sprayed with herbicide (glyphosate-containing) also before spring wheat sowing. Weed chemical control was successful in 2012 and 2014, weed density decreased significantly in sample plots. However, in 2013, after the use of herbicide weed density decreased minimally in some sample plots, but increased significantly in most sample plots (Fig. 1).

During each study year, the average daily temperature and the amount of precipitation was registered in sample plots, using the Davis Vantage Pro2 meteorological station located $100 \mathrm{~m}$ from the study stationary. The dynamics of meteorological factors is shown in Fig. 2.

Methods of ground beetle collection, processing and data analysis. Ground beetles were collected using the Barber pitfall trap - transparent plastic glasses dug into soil up to the upper edge. The trap-opening diameter was 65 $\mathrm{mm}$, but the capacity was $200 \mathrm{~cm}^{3}$. Ten traps in a diagonally drawn transect were installed in every sample plot; distance between the traps was $3 \mathrm{~m}$. Traps were half-filled with $4-5 \%$ acetic acid solution to which several drops of detergent were added for ground beetle fixing. During the first two study years, trap exhibition was started in spring, when the first active ground beetles were observed. It happened on April 172012 and on April 23 2013, respectively. During the third research year (2014) trap exhibition was started on April 22 or 
three days after the destroyed by frost winter wheat oversowing with spring wheat. The trapped beetles were removed and traps were filled with fresh acetic acid every seven days. Trap exhibition was finished on July 31 2012, July 30 2013 and on July 29 2014, respectively. During the first two research years, it was two and four days, respectively, before winter wheat cutting. Whereas, during the third year trap exhibition was finished 25 day before spring wheat cutting. Such decision was made, as it was not possible to obtain data for this 25day period from the first two research years.

The material of trapped ground beetles is appropriately labelled and stored in $70 \%$ solution of ethyl alcohol at the LLU Faculty of Agronomy Institute of Soil and Plant Sciences in Jelgava, Strazdu Street 1. Ground beetle species were determined using Central European beetle species identification key. Species names in this Doctoral Thesis have been used according to the check-list of Latvian beetles.

Ground beetle species assemblages were analysed by calculating species dominance structure according to the scale suggested by H.-D. Engelmann. According to this scale, species are divided into five groups depending on their proportion of individuals in species assemblage: eudominant species (40.0 $100.0 \%)$, dominant species $(12.5-39.9 \%)$, subdominant species $(4.0-12.4$ $\%)$, recedent species $(1.3-3.9 \%)$ and subrecedent species $(<1.3 \%)$. Both the summary and phenological calculation of dominance structure were carried out for each main soil treatment technique and pre-crop combination for each research year. In order to calculate the annual summary proportion of each species in sample plots with the corresponding agroecological factor combination, the number of individuals of a specific species and the number of all ground beetle individuals, who were trapped during the whole research season in all soil traps exhibited in corresponding sample plots, was used. For the phenological calculation, the number of individuals of each species and the number of all ground beetle individuals, who were trapped in all each factor combinations' sample plot traps during each seven-day research period, was used. Annual total estimates were made to analyse the effect of both agroecological factors on ground beetle species assemblages; however, the phenological calculations were made to determine the most commonly found species in wheat sowings during the vegetation season. Verification of activity density dependence on both agroecological factors and their combinations was performed on species that reached subdominant or higher status during at least one research period in at least one agroecological factor combination.

The total activity density dependence on both agroecological factors of the most common and all species was analysed using analysis of variance (ANOVA). If, while analysing, it was determined that the pre-crop statistically significantly $(\mathrm{p} \leq 0.05)$ affected the ground beetle activity density or the number of observed species during the season of 2012, or the both-factor combination during any research season, Scheffé's post-hoc test was used. The test 
determined, under which conditions created by pre-crop or factor combination the studied ground beetle parameters were significantly different. ANOVA and post-hoc test, if necessary, was performed for each research period, obtaining a picture of phenological factor effect on ground beetle activity density.

Ground beetle species diversity was determined by calculating the Simpson's index $\left(\mathrm{D}_{\mathrm{s}}\right)$ :

$$
D_{s}=\sum \frac{n_{i}\left(n_{i}-1\right)}{N(N-1)}
$$

where: $\quad n_{i}-$ the number of indexed ground beetle species individuals in traps;

$\mathrm{N}$ - the number of all ground beetle individuals in traps.

The bigger the species diversity, the smaller the numeric value of Simpson's index. Therefore, for a better transparency, the reciprocal Simpson's index $\left(1 / D_{s}\right)$, whose numeric value increases with increasing species diversity, was used in this study. The index was determined for all 120 traps used in every research season. Annual summary data of each trap was used for the index calculation - annual summary number of each ground beetle species individuals and annual summary number of all ground beetle individuals. Coherence between ground beetle species diversity and researched agroecological factors was evaluated by calculating Spearman's rank correlation coefficient $\left(r_{s}\right)$ with a two-tailed significance test. For each research season, correlation was calculated in seven different versions for the season of 2012 and in six different versions for the other two seasons:

1) between species diversity and main soil treatment method, regardless the pre-crop;

2) between species diversity and pre-crop, regardless the main soil treatment method;

3) between species diversity and pre-crop in harrowed soil;

4) between species diversity and pre-crop in ploughed soil;

5) between species diversity and main soil treatment method, if pre-crop is rape;

6) between species diversity and main soil treatment method, if pre-crop is winter wheat;

7) between species diversity and main soil treatment method, if pre-crop is spring wheat (only for the 2012 season).

The correlation strength was determined on such scale:

$\left|\mathrm{r}_{\mathrm{s}}\right|=0.00-0.19$ - very weak correlation;

$\left|\mathrm{r}_{\mathrm{s}}\right|=0.20-0.39-$ weak correlation;

$\left|\mathrm{r}_{\mathrm{s}}\right|=0.40-0.59$ - moderate correlation;

$\left|\mathrm{r}_{\mathrm{s}}\right|=0.60-0.79-$ strong correlation;

$\left|\mathrm{r}_{\mathrm{s}}\right|=0.80-1.00-$ very strong correlation.

All statistic calculations were performed using SPSS 22.0. Indices (beetles' activity density, reciprocal Simpson index) obtained with one trap were used as one replication. 


\section{Results}

Ground beetle species assemblages in differently managed wheat sowings. During all three research years, cumulatively, 113946 ground beetle individuals from 75 species were observed in sample plots. The number of observed individuals varies over the research seasons. During the first season, 25369 ground beetles were caught in traps, during the second season - 60024 ground beetles, and during the third season - 28563 ground beetles. Part of the species in sample plots were observed only during one or two research years. Thus, in 2012, 66 species were observed, in 2013 - 57 species and in $2014-45$ species.

Annual summary the most common or dominant ground beetle species assemblage formed mostly the same species during all research seasons. However, differences in these assemblages were observed between both variously managed sample plots within one research season and between various research seasons. During the season of 2012, eudominant species were not observed in any sample plot. Two species - Loricera pilicornis and Bembidion guttula - were the most dominant in all sample plots. Regardless of pre-crop, $L$. pilicornis was the most commonly observed species in harrowed sample plots, but B. guttula - in ploughed sample plots. Another six species - Bembidion obtusum, Poecilus cupreus, Harpalus rufipes, Pterostichus melanarius, Pterostichus niger and Amara plebeja - reached at least a subdominant state in sample plots with at least one main soil treatment method and pre-crop combination (Fig. 3).

In 2013, the most common ground beetle species assemblages in sample plots were formed by almost the same species as in 2012; however, the dominance structure was significantly different. Five species $-H$. rufipes, $P$. niger, $P$. melanarius, $P$. cupreus and $B$. guttula - reached at least subdominant status in the sample plots, but L. pilicornis was subdominant in all sample plots, except those with ploughed soil and winter wheat as pre-crop (Fig. 4). H. rufipes dominated significantly over other species in all sample plots, but it was most evident in the already mentioned sample plots with ploughed soil and winter wheat as pre-crop, where H. rufipes reached an eudominant state. Compared to the season of 2012, the proportion has increased significantly also for both Pterostichus species, as well as for $P$. cupreus. Whereas, the proportion of $B$. guttula and $L$. pilicornis had significantly decreased. Both species were able to reach the maximum subdominant state. However, A. plebeja and B. obtusum did not reach even a subdominant state in 2013 in any sample plot, though its activity density was comparatively high.

During the season of 2014, only five ground beetle species $-P$. melanarius, $P$. niger, $H$. rufipes, $P$. cupreus un $B$. guttula reached at least subdominant state in sample plots with at least one combination of pre-crop and main soil treatment method. The dominance structure in sample plots with 
harrowed soil and winter wheat as pre-crop differed the most from other dominance structures in other sample plots. $P$. melanarius was an eudominant species in these sample plots, $H$. rufipes - a dominant species, but $P$. niger - a subdominant species. The proportions of other species in these sample plots corresponded to recedent or subrecedent status. The mentioned three species reached a dominant status in other sample plots, but $P$. cupreus was subdominant. However, B. guttula reached subdominant level only in sample plots with rapeseed as pre-crop, regardless the main soil treatment methods (Fig. 5).

Ground beetle activity density and their proportion of individuals in species assemblage can vary significantly between different years. It is influenced directly and indirectly by meteorological conditions. The season of 2012, if compared to the other two, was colder and rainier. If there is a large amount of precipitation, more specimens of hygrophilic ground beetles can be found in agrocenoses, e.g., B. guttula. Precipitation also contributes to a higher density of springtails (Collembola) at top soil, yet springtails are the main feed for $L$. pilicornis. Air temperature can affect the reproduction cycles of ground beetles. The highest $P$. niger and $P$. melanarius population density is observed after comparatively cooler summers.

The proportion of several ground beetle species was affected by researched acroecological factors. The proportion of $L$. pilicornis during the first two seasons was remarkably higher in harrowed soil. $P$. niger was more commonly found in sample plots with crop rotation, but the proportion of $P$. melanarius had the tendency to be higher in sample plots without crop rotation. During the first research season, B. guttula preferred ploughed soil, but A. plebeja - harrowed soil in combination with spring wheat as a pre-crop; however, in other sample plots only some individuals of this species were observed. High proportion of A. plebeja formed in sample plots, where rather dense weed vegetation remained even after spraying with herbicides. Also in 2013, a large number of these individuals were observed in sample plots whose management regime (harrowed soil, winter wheat as a pre-crop) contributed to a significantly denser weed vegetation, however, the sharp increase of activity density of other species did not allow A. plebeja to attain at least a subdominant level in species assemblage.

It can be concluded that the main soil treatment method and pre-crop affect ground beetle species assemblage in wheat sowings. Therefore, it has the potential to be an IPM indicator; however, an additional study is needed, as other environmental factors, e.g., meteorological conditions, can have a significant impact on the proportion of the dominant species.

Ground beetle activity density dependence on pre-crop and main soil treatment method from phenological point of view. The most occurring ground beetle species, whose proportion of individuals reached a subdominant or higher level in at least one seven-day period in sample plots with at least one combination of main soil treatment method and pre-crop, were separated from 
the total amount of observed species in the research. During the three research years, total of 25 species correspond to such criteria (Table 1). Activity densities of 10 ground beetle species - Notiophilus aestuans, N. germinyi, Bembidion quadrimaculatum, Acupalpus meridianus, Platynus assimilis, Poecilus versicolor, Amara familiaris, A. ovata, A. similata and A. apricaria - were not affected by any of both studied agroecological factors. From these species, only A. meridianus corresponded with the most commonly observed species criteria during all three research seasons, other species, however, corresponded with the criteria only during one season.

The activity density of two species $-B$. guttula and $P$. niger reacted comparatively consistently to agroecological factors during all three seasons. Therefore, it is recommended to use these species as IPM indicators in wheat sowings. Both species need moderately moist environmental conditions, therefore, their activity density is significantly higher in sample plots whose management regime contributes to a denser wheat vegetation.

The activity density of $B$. guttula is positively affected by both ploughing and rapeseed as a pre-crop. Exception is the beginning of season 2014, when many individuals of this species were observed in harrowed sample plots, as the weed vegetation developed denser after sowing of spring wheat. However, during the second part of the same season, higher activity density of B. guttula was observed in the ploughed sample plots (Fig. 6). Thus, the activity density of B. guttula can be used as a positive IPM indicator in both sowings of winter and spring wheat. The most suitable period for observation of this species is July.

The activity density of $P$. niger was mainly affected by the pre-crop. This species has tried to avoid sample plots without crop rotation. During the first research season, positive effect of soil ploughing on the activity density of $P$. niger was also observed (Fig. 7). Therefore, this species can also be used as a positive IPM indicator in both sowings of winter and spring wheat. The most suitable period for $P$. niger observation is July.

The activity densities of other two species - Nebria brevicollis and A. plebeja - can be used as IPM indicators in winter wheat sowings. The activity density of $N$. brevicollis reacted positively to crop rotation. During the first two research seasons, significantly more individuals of this species were observed in sample plots with rapeseed as a pre-crop (Fig. 8). During the third season, when spring wheat was sown in sample plots, only some individuals of $N$. brevicollis were observed. Studies elsewhere in Europe show that this species almost never inhabits sowings of spring cereals, as the larvae of $N$. brevicollis, who overwinter on field, most probably perish during the sowing of spring crop. Thus, $N$. brevicollis can be used as a positive IPM indicator in winter wheat sowings. The most suitable period for species observation is June.

A. plebeja reacted significantly to both factor combination. In 2012, its activity density was significantly higher in harrowed sample plots with spring wheat as a pre-crop, but in 2013 - in harrowed sample plots with winter wheat 
as a pre-crop (Fig. 9). During both first research years, this species preferred sample plots whose management regime did not correspond to IPM principles and had allowed the development of rather dense perennial weed vegetation. During the third research year, these weeds were destroyed using a glyphosate containing herbicide, therefore, also A. plebeja was represented by separate individuals in sample plots. This species can be used as a negative IPM indicator in winter wheat sowings. The most suitable period for observations is July.

The activity density of other seven species - Anchomenus dorsalis, Bembidion properans, B. obtusum, Carabus cancellatus, Harpalus affinis, $P$. melanarius and Trechus quadristriatus - reacted significantly to studied agroecological factors. However, reaction could not be fully explained with current knowledge about ecology of these species. Therefore, for now these species can be considered potential IPM indicators that need additional research. Both A. dorsalis and C. cancellatus might be positive crop rotation indicators, as their activity density was significantly higher in sample plots with rapeseed as pre-crop. However, such coherence was observed only during the second research season. Most likely other ecological factors that are less known affect both these species. B. properans might be suitable as a negative IPM indicator, taking into account the environmental requirements of these species and following the results of second and third season, when the activity density of this species was significantly higher in harrowed soil. However, during the first season of the research, the dependence of this species on main soil treatment method was not clearly expressed and had an opposite tendency - higher activity density in ploughed soil. It is possible that $B$. obtusum can be used as a positive IPM indicator. During the first two research years, it was found that the activity density of this species can be significantly affected by both main soil treatment method and pre-crops. This species preferred sample plots with ploughed soil and/or rapeseed as a pre-crop. However, during the third year of the research, rather small number of $B$. obtusum individuals was observed in sample plots. This phenomenon cannot be explained yet, as the research sample plots are the first known locality in the Baltic region, where B. obtusum is one of the dominating species in wheat agrocenosis. This species is rare also in neighbouring countries of Latvia, but there is no data on the effect of spring crop sowing on its activity density. Thus, it is impossible to say, whether the low density of $B$. obtusum in spring wheat cenosis is related to specific agrotechnical conditions of spring crops, or there is another reason that might affect this species also in winter wheat sowings. The results of the second and third season showed that $H$. affinis might be a negative IPM indicator as this species preferred sample plots without crop rotation. However, during the first season, statistically significant differences in activity density between sample plots with different pre-crops were not found, though, the activity density of $H$. affinis was sufficiently high. It is possible that this phenomenon can be explained with the comparatively cold and rainy conditions of the first season, however, for the time 
being it is only an assumption. P. melanarius can also be used as a negative IPM indicator. In two research seasons, this species preferred sample plots without crop rotation and with harrowed soil. However, in one season, its activity density was significantly higher in sample plots with rapeseed as a pre-crop. $T$. quadristriatus is a potentially positive IPM indicator. During the first two research seasons, the activity density of this species was significantly higher in sample plots with ploughed soil and rapeseed as a pre-crop. However, during the third season, this species was almost not observed in sample plots, and this factor cannot be explained with current knowledge on species ecology. Thus, for the time being it is uncertain whether main soil treatment method and pre-crops are the only ecological factors that might significantly affect $T$. quadristriatus in wheat sowings.

The four ground beetle species, whose activity density reacted significantly to the researched agroecological factors, cannot be used as IPM indicators. The species are: Bembidion lampros, H. rufipes, L. pilicornis and $P$. cupreus. The activity density of $B$. lampros reacted significantly to the researched factors only during the second season. However, then this species preferred sample plots with rapeseed as a pre-crop, which is contrary to the present knowledge about the ecology of this species. H. rufipes either did not react to the researched agroecological factors, or the reaction was contradictory in the context of one season - at the beginning of season, the activity density was higher in sample plots with one pre-crop, in the sequel - with another pre-crop, but in the end - again with the first pre-crop. Thus, it can be concluded that main soil treatment and crop rotation is unlikely a limiting factors affecting this species in wheat sowings. The activity density of L. pilicornis during first two seasons was significantly higher in harrowed soil, if compared to ploughed soil, but during the third season, opposite coherence was observed. Moreover, during the second season the activity density of this species was positively affected by rapeseed as pre-crop. It means that during one season the species reacts positively to main soil treatment method, which is not considered a good IMP practice, and to crop rotation, which is considered a good IPM practice. A similar situation was observed with the activity density of $P$. cupreus, which was positively affected by rapeseed as a pre-crop and harrowed soil.

Total ground beetle activity density cannot be used as IPM indicator, as it reacted ambiguously to main soil treatment methods and pre-crops. During the first season, significant effect of pre-crop to the total ground beetle activity density was observed in separate periods, however, not during all these periods the same pre-crop contributed to greater activity of ground beetles. The second season was the only one, when rapeseed, and not winter wheat, as a pre-crop contributed to a significantly higher total activity density of ground beetles throughout the whole season. During the third season, main soil treatment method created a significant effect, but pre-crops did not affect the total activity density. Taking into account the results of the dependence of some most 
commonly found species activity density on agroecological factors, it should be concluded that the consistent reaction of total activity density to any of the factors is rather accidental. Total activity density will have the same reaction to a factor as the dominant species would react, with the precondition that the dominant species react equally to the factors. Due to this also the total activity density of different ground beetle species ecological groups cannot be used as IPM indicator. The effect of both agroecological factors on small ground beetles (body length $5 \mathrm{~mm}$ ) and medium and large ground beetles (body length $>5 \mathrm{~mm}$ ) was analysed within the research in 2012. It was found that the total activity density of small ground beetles is significantly higher in ploughed sample plots, but that of medium and large ground beetles - in harrowed sample plots. However, when it was found that the species of the same ecological group reacted differently on the main soil treatment methods and pre-crops, the analysis of total activity density of ground beetle ecological groups was not continued.

The influence of the main soil treatment method and pre-crop in wheat sowings on ground beetle species diversity. During all research seasons, the influence of main soil treatment method and pre-crop on ground beetle species diversity in sample plots was observed. However, the observed effect was not always the same during all three years. In 2012, the highest species diversity was observed in sample plots with two both factor combinations: ploughed soil and rapeseed as a pre-crop contributing to a denser wheat vegetation (1), harrowed soil and spring wheat as a pre-crop contributing to a weaker wheat vegetation compensated by a denser weed vegetation (2). In both cases, the sample plot vegetation has contributed to increased resources of shelters and food for ground beetles by attracting phytophagous invertebrates or promoting the presence of weed seeds. Species diversity was significantly lower in other sample plots. The lowest species diversity in harrowed sample plots and rapeseed as a pre-crop cannot be explained (Fig. 10).

In 2013, rapeseed as pre-crop contributed to a higher species diversity in all sample plots. However, a statistically significant difference was observed only in ploughed sample plots. Harrowed soil in combination with winter wheat as a pre-crop contributed to an equal ground beetle species diversity due to dense weed vegetation, as did rapeseed as pre-crop, regardless of main soil treatment. The main soil treatment method, regardless of pre-crops, also significantly affected species diversity. During the second year of the research, higher species diversity was found in harrowed soil than in ploughed soil (Fig. 11). This can be explained with a less successful weed control using herbicides in 2013 than in a previous year. Weed density did not decrease in all harrowed sample plots after spraying with herbicides; however, in several harrowed sample plots it increased significantly.

During the third research season, a more intense weed control was performed in sample plots. Perennial weed vegetation, which was better developed in sample plots without crop rotation and harrowed soil, was destroyed 
before sowing of spring wheat using glyphosate-containing preparation. Herbicide spraying was also effective during growing season. Weed density was similarly low in all sample plots after it. As a result, the highest species diversity was observed in sample plots with rapeseed as a pre-crop, but main soil treatment method had no significant effect in these sample plots. Significantly higher species diversity in sample plots with winter wheat as a pre-crop was observed if soil was ploughed (Fig. 12).

Ground beetle species diversity might be a more suitable IPM indicator than species assemblage. The study showed that significant differences of ground beetle species diversity existed between sample plots with various management regimes. However, one significant obstacle for the use of species diversity as an indicator exists yet. The first two research years showed that the higher species diversity is observed in both sample plots that are managed according to the good IPM practice and in sample plots whose management does not correspond to a good IPM practice principles; yet, the high ground beetle species diversity was secured with a long-lasting weed vegetation in them. Due to this reason, additional research on ground beetle species diversity in wheat sowings with diverse main soil treatment method and different pre-crops is needed. One of the addition research directions might be analysis of species diversity from phenological aspect. Thus it might be possible to verify, whether the ground beetle species diversity significantly differs during separate vegetation season periods among wheat sowings that are managed according to a good IPM practice and other sowings, where good IPM practice is not implemented, and weed control does not leave an effect on ground beetles. 


\section{Conclusions}

1. Ground beetle species assemblage in researched wheat sowings was formed by 75 species, of which the most dominant were Bembidion guttula, Loricera pilicornis, Harpalus rufipes, Poecilus cupreus, Pterostichus melanarius and $P$. niger.

2. Ground beetle species assemblages were affected by diverse main soil treatment methods and different pre-crops in wheat sowings. Species proportion might change significantly depending on the manifestation of agroecological factors, however, the main dominant species mostly remained the same regardless of wheat sowing management regime.

3. One or both agroecological factors significantly influenced activity density of fifteen ground beetles species: Amara plebeja, Anchomenus dorsalis, $B$. guttula, B. lampros, B. properans, B. obtusum, Carabus cancellatus, Harpalus affinis, H. rufipes, L. pilicornis, Nebria brevicollis, P. cupreus, $P$. melanarius, $P$. niger and Trechus quadristriatus. Both factor combination influenced the activity density of one species $-A$. plebeja.

4. The main soil treatment method and pre-crops significantly influenced ground beetle species diversity in wheat sowings. Two wheat sowing management regimes contributed to a higher species diversity: ploughed soil and rapeseed as a pre-crop (1), harrowed soil and no crop rotation (2). In the case of second management regime, high species diversity was observed if weed control was insufficiently successful in wheat sowings.

5. The activity density of four species - B. guttula, P. niger, A. plebeja and N. brevicollis - can be used as IPM indicators in wheat sowings. A. plebeja and $N$. brevicollis can be used as indicators only in winter wheat sowings, but other two species can be used in both winter and spring wheat sowings.

6. Potentially, ground beetle species assemblage, ground beetle species diversity index and the activity density of seven species $-A$. dorsalis, $B$. obtusum, B. properans, $C$. cancellatus, $H$. affinis, $P$. melanarius and $T$. quadristriatus, might be used as IPM indicators in wheat sowings. Species diversity index might be a more suitable indicator than species assemblage. However, additional research on these parameters is needed.

7. The total activity density of ground beetle species, the total activity density of various ground beetle species ecological groups, as well as the activity densities of four species - B. lampros, $H$. rufipes, $P$. cupreus and $L$. pilicornis - cannot be used as IPM indicators in wheat sowings 